\title{
New insights into the atmospheric mercury cycling in central Antarctica and implications on a continental scale
}

\author{
Hélène Angot $^{1}$, Olivier Magand ${ }^{2,1}$, Detlev Helmig ${ }^{3}$, Philippe Ricaud ${ }^{4}$, Boris Quennehen ${ }^{2,1}$, Hubert Gallée ${ }^{2,1}$, \\ Massimo Del Guasta $^{5}$, Francesca Sprovieri ${ }^{6}$, Nicola Pirrone ${ }^{7}$, Joël Savarino ${ }^{2,1}$, and Aurélien Dommergue ${ }^{1,2}$ \\ ${ }^{1}$ Univ. Grenoble Alpes, Laboratoire de Glaciologie et Géophysique de l'Environnement (LGGE), 38041 Grenoble, France \\ ${ }^{2}$ CNRS, Laboratoire de Glaciologie et Géophysique de l'Environnement (LGGE), 38041 Grenoble, France \\ ${ }^{3}$ Institute of Arctic and Alpine Research (INSTAAR), University of Colorado, Boulder, CO 80309-0450, USA \\ ${ }^{4}$ CNRM/GAME, Météo-France/CNRS, 42 avenue de Coriolis, 31057 Toulouse, France \\ ${ }^{5}$ CNR-Istituto Nazionale di Ottica, Largo E. Fermi 6, Firenze, 50125, Italy \\ ${ }^{6} \mathrm{CNR}$-Institute of Atmospheric Pollution Research, Division of Rende, Italy \\ ${ }^{7}$ CNR-Institute of Atmospheric Pollution Research, Montelibretti, Rome, Italy
}

Correspondence to: Aurélien Dommergue (aurelien.dommergue@univ-grenoble-alpes.fr)

Received: 16 February 2016 - Published in Atmos. Chem. Phys. Discuss.: 18 February 2016

Revised: 14 June 2016 - Accepted: 27 June 2016 - Published: 8 July 2016

\begin{abstract}
Under the framework of the GMOS project (Global Mercury Observation System) atmospheric mercury monitoring has been implemented at Concordia Station on the high-altitude Antarctic plateau $\left(75^{\circ} 06^{\prime} \mathrm{S}, 123^{\circ} 20^{\prime} \mathrm{E}\right.$, $3220 \mathrm{~m}$ above sea level). We report here the first year-round measurements of gaseous elemental mercury $(\mathrm{Hg}(0))$ in the atmosphere and in snowpack interstitial air on the East Antarctic ice sheet. This unique data set shows evidence of an intense oxidation of atmospheric $\mathrm{Hg}(0)$ in summer (24-hour daylight) due to the high oxidative capacity of the Antarctic plateau atmosphere in this period of the year. Summertime $\mathrm{Hg}(0)$ concentrations exhibited a pronounced daily cycle in ambient air with maximal concentrations around midday. Photochemical reactions and chemical exchange at the air-snow interface were prominent, highlighting the role of the snowpack on the atmospheric mercury cycle. Our observations reveal a 20 to $30 \%$ decrease of atmospheric $\mathrm{Hg}(0)$ concentrations from May to mid-August (winter, $24 \mathrm{~h}$ darkness). This phenomenon has not been reported elsewhere and possibly results from the dry deposition of $\mathrm{Hg}(0)$ onto the snowpack. We also reveal the occurrence of multi-day to weeklong atmospheric $\mathrm{Hg}(0)$ depletion events in summer, not associated with depletions of ozone, and likely due to a stagnation of air masses above the plateau triggering an accumulation of oxidants within the shallow boundary layer. Our observations suggest that the inland atmospheric reser-
\end{abstract}

voir is depleted in $\operatorname{Hg}(0)$ in summer. Due to katabatic winds flowing out from the Antarctic plateau down the steep vertical drops along the coast and according to observations at coastal Antarctic stations, the striking reactivity observed on the plateau most likely influences the cycle of atmospheric mercury on a continental scale.

\section{Introduction}

Mercury biomagnifies in its methylated form in aquatic food webs to elevated levels in freshwater and marine fish, causing adverse health effects to wildlife and humans (Mason et al., 2012). In 2013, the Minamata Convention (UNEP, 2013) was adopted and opened for signature to reduce the exposure of populations to this worldwide contaminant. Gaseous elemental mercury $(\operatorname{Hg}(0))$, the most abundant form of mercury in the atmosphere, is efficiently transported around the globe, and even remote areas receive significant inputs of anthropogenic mercury by long-range atmospheric transport, as recently reported in modeling and observational studies (Weiss-Penzias et al., 2007; Lin et al., 2010).

$\mathrm{Hg}(0)$ can be oxidized into highly reactive and watersoluble gaseous and/or particulate divalent species ( $\mathrm{Hg}$ (II) and $\mathrm{Hg}(\mathrm{p})$, respectively) (Lin and Pehkonen, 1999) leading to the formation and subsequent deposition of reactive mercury 
onto environmental surfaces (Hedgecock and Pirrone, 2004). Upon deposition, mercury can be re-emitted back to the atmosphere or may enter the food chain through the conversion of $\mathrm{Hg}$ (II) to its methylated form (Driscoll et al., 2013). Effects and toxicity of mercury depends on this complex cycle, which is still not fully understood, and are only indirectly related to regional and global emissions (Driscoll et al., 2013). A better understanding of atmospheric mercury chemistry will lead to improved global transport and deposition models and could help refine pollution-control strategies around the world.

New oxidation pathways, discovered in 1995 in the Arctic (Schroeder et al., 1998) and highlighting the influence of halogen radicals on $\operatorname{Hg}(0)$ oxidation in spring, changed our understanding of the mercury cycle. While the Arctic has been extensively monitored, there is still much to be learned from the Antarctic continent where studies are scarce (Dommergue et al., 2010), especially on the high altitude plateau (Fig. 1). The Antarctic plateau - ice-covered area of $\sim 7$ million $\mathrm{km}^{2}$ - was first considered to be chemically inactive and a giant cold trap for atmospheric species (e.g., Lambert et al., 1990). It turned out to be highly photochemically active (Davis et al., 2001; Grannas et al., 2007) during the sunlit period with oxidant concentrations approaching those of tropical or urban mid-latitude environments (Eisele et al., 2008; Kukui et al., 2014). Earlier studies (Brooks et al., 2008; Dommergue et al., 2012) - the only two mercury studies ever carried out on the high-altitude Antarctic plateau with modern instruments - also suggested, based on short-term observations (a few weeks) in summer, an intense reactivity of mercury on the plateau at the air-snow interface. In this context, and under the framework of the GMOS project (Global Mercury Observation System, www.gmos.eu), atmospheric mercury was continuously monitored at Concordia Station (Fig. 1) since 2012 and, for the first time, $\operatorname{Hg}(0)$ has been monitored year-round in both the snow interstitial air and the overlying atmosphere in 2013. Given harsh weather conditions (see Sect. 2.1), and technical and logistical limitations, presenting such a record is in itself an important achievement. The main objective of this study is to provide new insights into the year-round cycling of gaseous mercury on the Antarctic plateau.

\section{Experimental section}

\subsection{Sampling site}

Year-round measurements of gaseous mercury were conducted in 2012 and 2013 at the French/Italian Concordia Station $\left(75^{\circ} 06^{\prime} \mathrm{S}, 123^{\circ} 20^{\prime} \mathrm{E}, 3220 \mathrm{~m}\right.$ above sea level), located on the Antarctic plateau, $1100 \mathrm{~km}$ away from the nearest coast of East Antarctica (Fig. 1). Concordia Station is a regional topographic maximum on the plateau; the surface terrain slopes do not exceed $1 \%$ (Genthon et al., 2010).

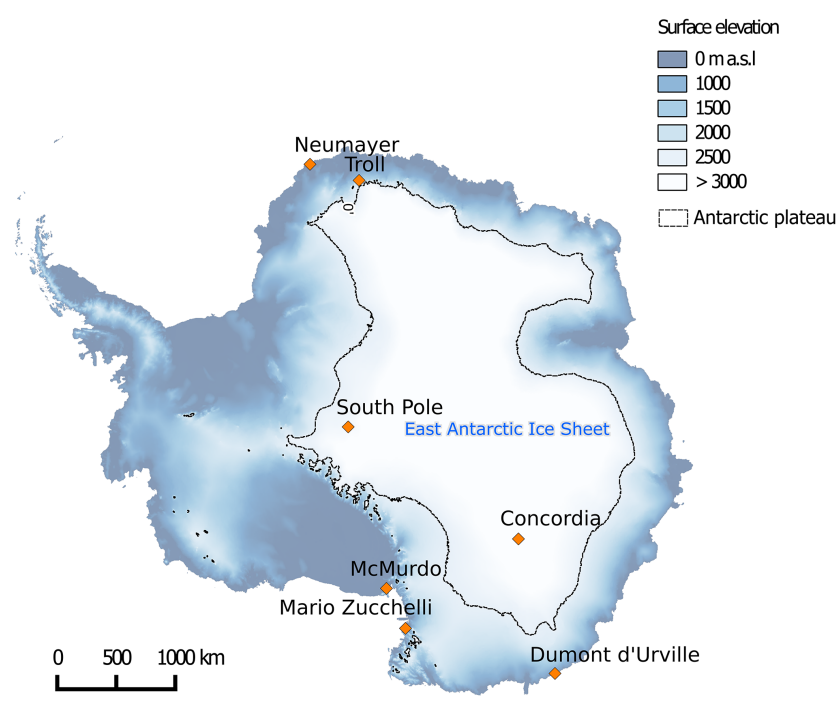

Figure 1. Map of Antarctica showing surface elevation (meters above sea level, ma.s.1.) and the position of stations where atmospheric mercury measurements have been performed with modern on-line instruments. The black line shows the periphery of the high altitude plateau (>2500 $\mathrm{m}$ a.s.1.).

The air temperature ranges between $-20^{\circ} \mathrm{C}$ in summer and $-70^{\circ} \mathrm{C}$ in winter, with an annual mean value of $-45^{\circ} \mathrm{C}$ (Pietroni et al., 2012). There is permanent daylight in summer and permanent darkness in winter. Snow accumulation is $\sim 10 \mathrm{~cm}_{\text {year }}{ }^{-1}$ (Genthon et al., 2013).

\subsection{Sampling instrumentation}

Instrumentation was located in a below-surface shelter at the edge of the "clean area", $800 \mathrm{~m}$ away from the main camp and upwind with respect to the dominant wind direction (south west). In 2012, year-round measurements were performed in the atmospheric boundary layer at about $500 \mathrm{~cm}$ above the snow surface. In 2013, measurements were performed in both the atmosphere and in snowpack interstitial air for several trace gases including gaseous mercury and ozone $\left(\mathrm{O}_{3}\right)$. Sampling instrumentation included one $10 \mathrm{~m}$ meteorological tower for above-surface gradient sampling and two multi-inlet snow sampling manifolds ("snow towers") for measuring trace gases at various depths in interstitial air (Bocquet et al., 2007; Seok et al., 2009). The $10 \mathrm{~m}$ meteorological tower was installed $\sim 15 \mathrm{~m}$ upwind of the underground instrument shelter. It accommodated three gas inlets at 1070,210 , and $25 \mathrm{~cm}$ above the snow surface (Fig. 2a). Trace gas measurements were acquired on each snow tower at six height levels: 50 and $10 \mathrm{~cm}$ above the snow surface, and 10, 30, 50, and $70 \mathrm{~cm}$ below the snow surface (Fig. 2b). Sampling lines were purged continuously at $5 \mathrm{~L} \mathrm{~min}^{-1}$ on the meteorological tower and intermittently at $\sim 2-3 \mathrm{~L} \mathrm{~min}^{-1}$ on the snow towers. On each snow tower, inlets were fitted with a small glass fiber filter in PTFE housing ( $25 \mathrm{~mm}$ Acrodisc sy- 


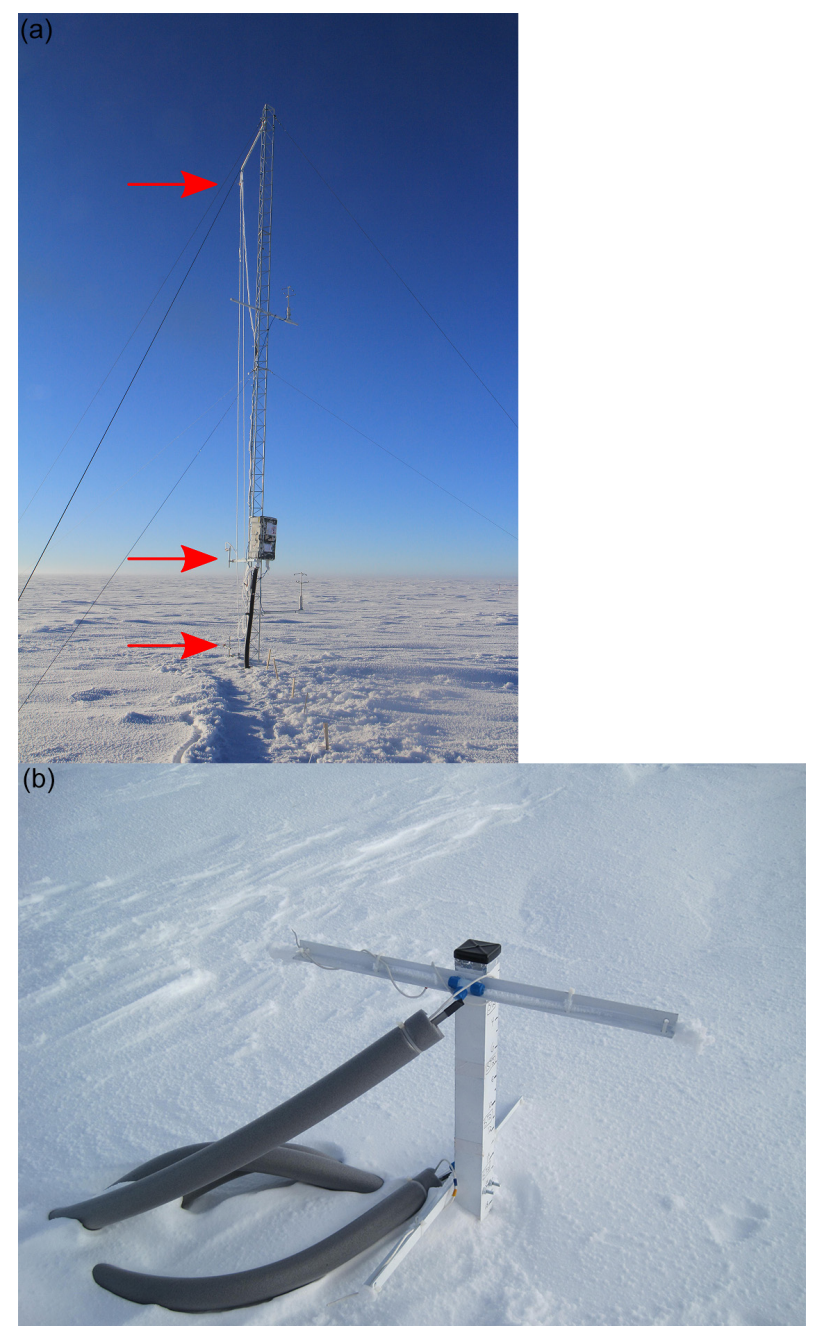

Figure 2. Photographs showing (a) the meteorological tower with the three gas inlets (red arrows) at 1070, 210 and $25 \mathrm{~cm}$ above the snow surface (photo credit: B. Jourdain), and (b) one of the snow towers with the two sampling inlets above the snowpack at 50 and $10 \mathrm{~cm}$ (photo credit: D. Helmig).

ringe filters, Pall Life Sciences, Ann Arbor, Michigan, USA) to prevent snow crystals from entering the PFA sampling lines. Sampling lines were inside insulation tubing and the temperature of the sampling lines was maintained at a level $5-10^{\circ} \mathrm{C}$ warmer than the snowpack temperature with a heat trace to prevent water vapor from freezing and clogging the lines. An automatic sampling pattern was implemented: trace gases were collected sequentially from the uppermost inlets on the meteorological tower to deepest levels of the snow towers. Measurements were taken for $10 \mathrm{~min}$ from each inlet.

\subsection{Gaseous mercury measurements}

Measurements were performed using a Tekran 2537A analyzer (Tekran Inc., Toronto, Canada) based on the amalga- mation of mercury onto a gold cartridge followed by thermal desorption and detection by an integrated cold vapor atomic fluorescence spectrometer (CVAFS) at $253.7 \mathrm{~nm}$ (Fitzgerald and Gill, 1979; Bloom and Fitzgerald, 1988). The presence of two gold cartridges allowed alternating sampling and desorption modes and thus a continuous analysis in the pre-filtered $(0.45 \mu \mathrm{m}$ PTFE filter) and unheated sample air stream. The sampling resolution was 5 min with a sampling flow rate of $0.8 \mathrm{~L} \mathrm{~min}^{-1}$. Concentrations are expressed in nanograms per cubic meter at standard temperature and pressure $(273.15 \mathrm{~K}$, $1013.25 \mathrm{hPa}$ ). Using both a $0.45 \mu \mathrm{m}$ PTFE filter at the entrance inlet of the sample line, and an unheated $\frac{1}{4}$ 'PTFE sample line, we assume that only $\mathrm{Hg}(0)$ (vs. total gaseous mercury, defined as the sum of gaseous mercury species) was efficiently collected and subsequently analyzed in this study (Steffen et al., 2002; Temme et al., 2003; Steffen et al., 2008).

\section{Quality assurance and quality control procedures}

An automatic calibration step of the Tekran 2537A analyzer was carried out every $25 \mathrm{~h}$ with an internal mercury permeation source. External calibrations were performed twice a year by manually injecting saturated mercury vapor taken from a temperature-controlled vessel (Tekran 2505 mercury vapor calibration unit, Hamilton digital syringe). As described by Angot et al. (2014), bi-monthly to monthly routine maintenance operations were performed. A software program was developed at the LGGE (Laboratoire de Glaciologie et Géophysique de l'Environnement) in accordance with quality control practice in well-established North American networks (Steffen et al., 2012). Based on various flagging criteria (Munthe et al., 2011; D'Amore et al., 2015), it enabled rapid data processing in order to produce clean time series of $\mathrm{Hg}(0)$. The detection limit is estimated at $0.10 \mathrm{ng} \mathrm{m}^{-3}$ (Tekran, 2011). Based on experimental evidence, the average systematic uncertainty for $\mathrm{Hg}(0)$ measurements is of $\sim 10 \%$ (Slemr et al., 2015).

\subsection{Surface snow sampling and analysis}

Surface snow samples (first $\mathrm{cm}$ ) were collected weekly from February 2013 to January 2014 using acid cleaned PTFE bottles and clean sampling procedures. Upon collection, samples were stored in the dark at $-20^{\circ} \mathrm{C}$. Field blanks, carried out by opening and closing a bottle containing mercury-free water, were regularly conducted. Surface snow samples and field blanks were analyzed for total mercury using a Tekran Model 2600. The instrument was calibrated with the NIST SRM-3133 mercury standard. Quality assurance and quality control included the analysis of analytical blanks, replicates, and internal standards (reference waters for mercury: HG102-2 at $22 \mathrm{ng} \mathrm{L}^{-1}$ from Environment Canada). The limit of quantification - calculated as 10 times the standard deviation of a set of three analytical blanks - amounted to $0.3 \mathrm{ng} \mathrm{L}^{-1}$ with a relative accuracy of $\pm 8 \%$. 


\subsection{Ancillary parameters}

\subsubsection{Ozone}

Measurements were performed using a UV absorption monitor (Thermo Electron Corporation, Franklin, MA), model 49I in 2012 (Legrand et al., 2016) and model 49C in 2013. In 2013, the instrument was calibrated against the standard of the National Oceanic and Atmospheric Administration Global Monitoring Division, Boulder, Colorado.

\subsubsection{Air mass back trajectories}

Air mass back trajectories were computed using the Lagrangian model FLEXPART (Stohl et al., 1998; Stohl and Thomson, 1999; Stohl et al., 2005) run in the backward mode and driven by NCEP (National Center for Environmental Predictions) GFS (Global Forecast System) final meteorological fields. Simulations were done every day at 12:00 UTC in 2012 and 2013. For each simulation, 20000 pseudo-particles were released by the model around the position of Concordia Station and tracked for 5 days in three layers of altitude (0$0.1,0.1-4$, and $4-10 \mathrm{~km}$ above ground level). Simulations at an altitude of 4-10 km were computed in order to investigate the potential occurrence of upper troposphere/lower stratosphere intrusions. For each $1 \mathrm{~h}$ time step, the model produced a normalized particle residence time (in seconds) within an output grid of $0.5 \times 0.5^{\circ}$. The sum of the 5 days' outputs provided potential emission sensitivities (PES, in seconds) for the three layers of altitude. PES in a particular grid cell is proportional to the particle residence time in that cell. It should be noted that, in Antarctica, the meteorological data driving the FLEXPART transport model rely on sparse measurements. Consequently, the trajectories calculated in this region are often associated with relatively high uncertainties.

\subsubsection{Height of the boundary layer and shortwave radiation}

The height of the boundary layer and downwelling shortwave radiation were calculated by the MAR regional atmospheric model (Modèle Atmosphérique Régional). MAR was developed at the LGGE for polar regions and the simulations have been evaluated against meteorological observations made at Concordia Station (Gallée and Gorodetskaya, 2010; Gallée et al., 2015).

\subsubsection{Meteorological data}

Temperature, wind speed and direction were recorded at six height levels on a $45 \mathrm{~m}$ tower. The general observation set up is described by Genthon et al. (2010).

\subsubsection{Ice precipitation}

A tropospheric depolarization lidar (light detection and ranging) operating at $523 \mathrm{~nm}$ provided tropospheric profiles of aerosol and clouds every $5 \mathrm{~min}$, allowing detection of water/ice clouds, snow drift, diamond dust, and pollution plumes.

\subsubsection{Tropospheric temperature and integrated water vapor}

A $\mathrm{H}_{2} \mathrm{O}$ Antarctica Microwave Stratospheric and Tropospheric Radiometers (HAMSTRAD) instrument was used for the detection of the $60 \mathrm{GHz}$ oxygen and the $183 \mathrm{GHz}$ water vapor lines, allowing measurement of tropospheric temperature and water vapor profiles, respectively, together with integrated water vapor (IWV) every $7 \mathrm{~min}$. The instrument is fully automated and a liquid nitrogen calibration is performed twice per year (Ricaud et al., 2015)

\subsubsection{Eddy diffusivity and friction velocity}

The Eddy diffusivity was calculated as follows (Xiao et al., 2014):

$K=k u_{*} z / \varphi_{h}$,

where $k$ (set to 0.40 ) is the von Karman constant, $u_{*}$ the friction velocity $\left(\mathrm{m} \mathrm{s}^{-1}\right), z$ the measurement height $(\mathrm{m})$, and $\varphi_{h}$ the Obukhov stability function. According to Frey et al. (2013), the stability function was $\varphi_{h}=0.95+4.62 \frac{z}{L}$ for stable conditions above snow (King and Anderson, 1994), and $\varphi_{h}=0.95\left(1-11.6 \frac{z}{L}\right)^{-0.5}$ for unstable conditions (Hoegstroem, 1988). $u_{*}$ and $L$ (the Obukhov length, $\mathrm{m})$ were computed from the three-dimensional wind components $(u, v, w)$ and temperature measured by a Metek sonic anemometer mounted at $8 \mathrm{~m}$ above the snow surface.

\section{Results and discussion}

\section{1 $\mathrm{Hg}(0)$ concentrations in ambient air}

The record of atmospheric $\operatorname{Hg}(0)$ over the entire 20122013 period is displayed in Fig. 3a. $\operatorname{Hg}(0)$ concentrations ranged from below 0.10 to $2.30 \mathrm{ng} \mathrm{m}^{-3}$, with average values amounting to $0.76 \pm 0.24 \mathrm{ng} \mathrm{m}^{-3}$ in 2012 , and to $0.81 \pm 0.28,0.84 \pm 0.27$, and $0.82 \pm 0.26 \mathrm{ng} \mathrm{m}^{-3}$ in 2013 at 25,210 , and $1070 \mathrm{~cm}$ above the snow surface, respectively. No significant difference was observed between annual averages of $\mathrm{Hg}(0)$ concentrations measured at the three inlets of the meteorological tower in 2013 ( $p$ value $=3.1 \times 10^{-14}$, Mann-Whitney test). It should be noted that $\operatorname{Hg}(0)$ concentrations at the three inlets were significantly different in winter only (see Sect. 3.1.4). These mean annual $\mathrm{Hg}(0)$ concentrations are lower than annual averages reported at near-coastal or coastal Antarctic stations (i.e., 


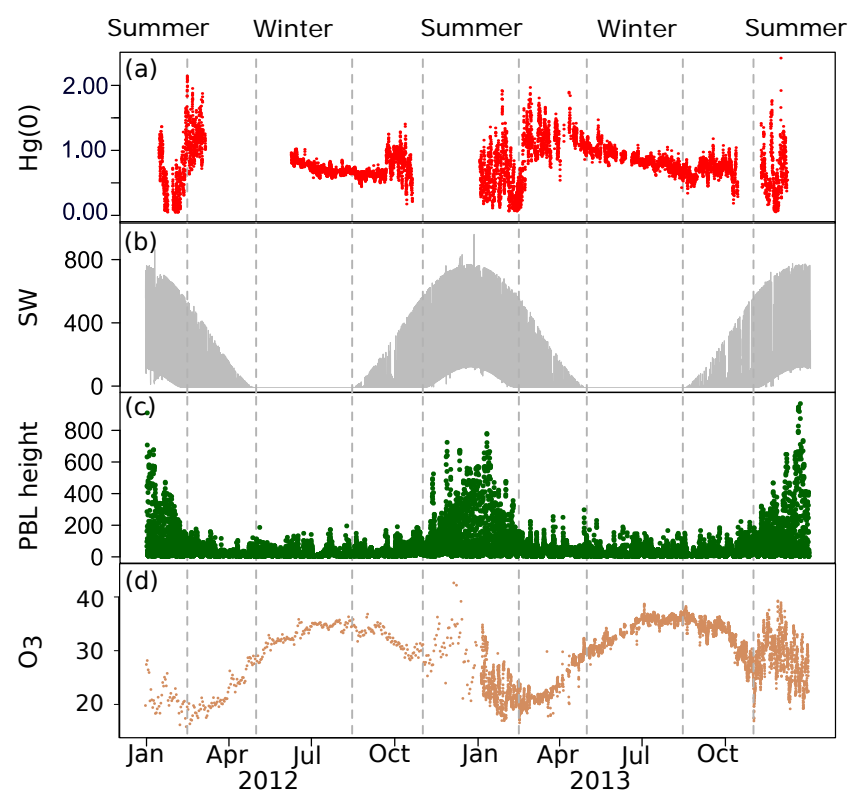

Figure 3. Annual variation in 2012 and 2013 of (a) hourly averaged $\mathrm{Hg}(0)$ concentrations (in $\mathrm{ng} \mathrm{m}^{-3}$ ) at 500 and $25 \mathrm{~cm}$ above the snow surface in 2012 and 2013, respectively, (b) downwelling shortwave (SW) radiation (in $\mathrm{W} \mathrm{m}^{-2}$ ), (c) planetary boundary layer (PBL) height (in $\mathrm{m}$ ), and (d) ozone $\left(\mathrm{O}_{3}\right.$, daily mean in 2012 and hourly mean in 2013) mixing ratios (in ppbv). The vertical dashed lines represent seasonal boundaries.

$0.93 \pm 0.19 \mathrm{ng} \mathrm{m}^{-3}$ for $\operatorname{Hg}(0)$ at Troll, Pfaffhuber et al., 2012; and $1.06 \pm 0.24 \mathrm{ng} \mathrm{m}^{-3}$ for total gaseous mercury at Neumayer, Ebinghaus et al., 2002).

The seasonal boundaries are defined according to the transitions in downwelling shortwave radiation (see Fig. 3b) as follows: winter from May to mid-August, spring from mid-August to October, summer from November to midFebruary, and fall from mid-February to April. Unlike in winter, $\operatorname{Hg}(0)$ concentrations were highly variable during the sunlit period with concentrations ranging from below 0.10 to $1.50-2.00 \mathrm{ng} \mathrm{m}^{-3}$, up to twice the average background levels recorded in the Southern Hemisphere mid-latitudes (Slemr et al., 2015). These seasonal features, in good agreement with observations at other Antarctic stations (Ebinghaus et al., 2002; Pfaffhuber et al., 2012), suggest the existence of a photochemically induced reactivity of atmospheric mercury during the sunlit period. The mechanisms which cause the seasonal variation of $\mathrm{Hg}(0)$ concentrations are discussed in the following sections.

\subsubsection{Spring}

First discovered in the Arctic (Schroeder et al., 1998), atmospheric $\mathrm{Hg}(0)$ depletion events (AMDEs) result from an oxidation by reactive bromine species released during springtime so-called "bromine explosions" in coastal regions (Durnford and Dastoor, 2011 and references therein) and
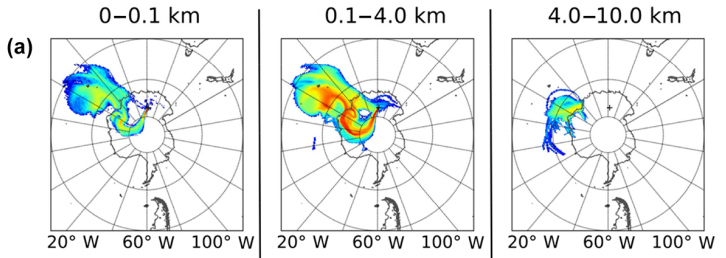

(b)
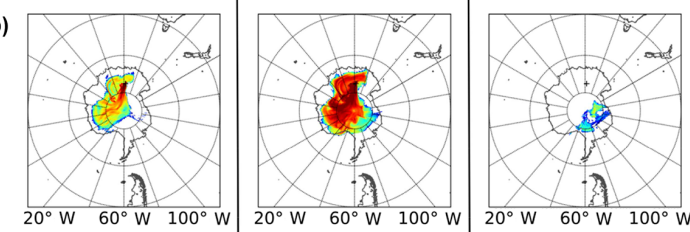

PES ( $s)$

(c)
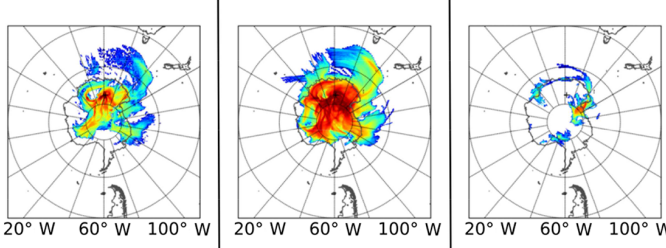

(d)
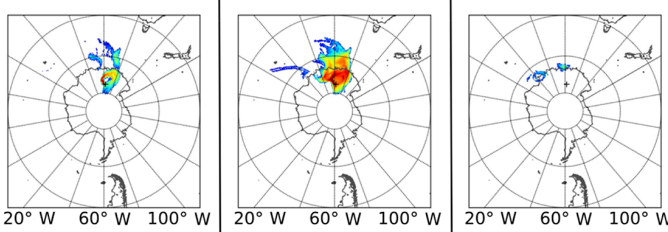

(e)
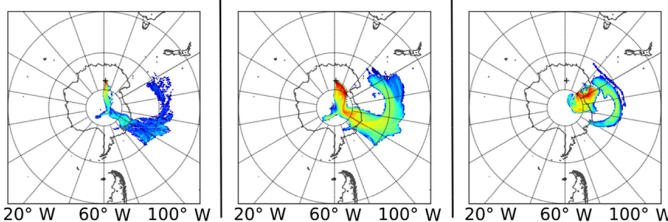

Figure 4. Back trajectories for the three layers of altitude colored according to the potential emission sensitivity (PES, in seconds) (a) on 11 September 2013, (b) from 19 January to 8 February 2012, (c) from 5 to 20 February 2013, (d) on 10 February 2012, and (e) on 22 February 2013. Note that PES in a particular grid cell is proportional to the particle residence time in that cell.

are concurrent with tropospheric $\mathrm{O}_{3}$ depletion events (Simpson et al., 2007). Despite the distance of Concordia Station from the coast $(1100 \mathrm{~km})$, a $\mathrm{Hg}(0)$ depletion event was observed on 11 September 2013 due to a maritime air transport event (Fig. 4a). During this event, $\mathrm{Hg}(0)$ concentrations dropped from 0.85 to $0.56 \mathrm{ng} \mathrm{m}^{-3}$ and exhibited a strong positive correlation with $\mathrm{O}_{3}$ mixing ratios $($ rho $=0.94, p$ value $=$ $\left.5 \times 10^{-7}\right)$.

\subsubsection{Summertime}

\section{(a) Oxidation of $\mathrm{Hg}(0)$ in ambient air and $\mathrm{Hg}$ (II) deposition onto snowpack}

In summer, the mean atmospheric $\mathrm{Hg}(0)$ concentration was $0.69 \pm 0.35 \mathrm{ng} \mathrm{m}^{-3}$ (mean \pm standard deviation). This means that $\mathrm{Hg}(0)$ concentrations are $\sim 25 \%$ lower than levels recorded at the same period of the year at coastal Antarc- 
tic stations (Ebinghaus et al., 2002; Sprovieri et al., 2002; Pfaffhuber et al., 2012). Total mercury concentrations in surface snow samples were highly variable (median value: $4.8 \mathrm{ng} \mathrm{L}^{-1}$, range: < detection limit $-73.8 \mathrm{ng} \mathrm{L}^{-1}$, Fig. 5) and were higher in summer (median value: $10.4 \mathrm{ng} \mathrm{L}^{-1}$, range: $1.3-73.8 \mathrm{ng} \mathrm{L}^{-1}$ ), suggesting that divalent mercury species were preferentially deposited onto the snowpack in this period of the year. The lower $\operatorname{Hg}(0)$ concentrations in ambient air along with high total mercury concentrations in surface snow samples suggest an intense oxidation of $\mathrm{Hg}(0)$ in ambient air in summer, followed by the deposition of oxidation products on surface snow. This hypothesis is further supported by elevated oxidized mercury concentrations measured on the Antarctic plateau at South Pole in summer (0.10-1.00 $\mathrm{ng} \mathrm{m}^{-3}$ ) by Brooks et al. (2008).

The oxidative capacity of the Antarctic plateau atmosphere is elevated in summer, as evidenced by several studies (Davis et al., 2001; Grannas et al., 2007; Eisele et al., 2008; Kukui et al., 2014), likely explaining this intense oxidation of $\mathrm{Hg}(0)$ in ambient air. Among these oxidants, $\mathrm{NO}_{2}, \mathrm{RO}_{2}$, and $\mathrm{OH}$ are particularly abundant at Concordia Station in summer (Frey et al., 2013; Kukui et al., 2014) and a recent study provided as a first estimate a $\mathrm{BrO}$ mixing ratio of 2-3 pptv near the ground during sunlight hours (Frey et al., 2015). Given the current understanding of mercury oxidation and the lack of continuous halogens measurements, we were not able to identify the exact mechanism for the reactivity observed at Concordia Station. A two-step oxidation mechanism, favored at cold temperatures, is worth being considered further. The initial recombination of $\mathrm{Hg}(0)$ and $\mathrm{Br}$ is followed by the addition of a second radical (e.g., I, Cl, $\mathrm{BrO}$, $\mathrm{ClO}, \mathrm{OH}, \mathrm{NO}_{2}$, or $\mathrm{HO}_{2}$ ) in competition with thermal dissociation of the $\mathrm{HgBr}$ intermediate (Goodsite et al., 2004; Wang et al., 2014). According to Dibble et al. (2012), $\mathrm{HO}_{2}$, NO, $\mathrm{NO}_{2}$, and $\mathrm{NO}_{3}$ bind $\mathrm{Hg}(0)$ too weakly to initiate its oxidation in the gas phase and reactions of the $\mathrm{HgBr}$ intermediate with $\mathrm{NO}_{2}, \mathrm{HO}_{2}, \mathrm{ClO}$, and $\mathrm{BrO}$ are more important than with $\mathrm{Br}$ and $\mathrm{OH}$. Further modeling or laboratory chamber studies investigating the fate of $\mathrm{Hg}(0)$ in the presence of various potential oxidants are needed to improve our understanding of the mechanisms.

\section{(b) Multi-day depletion events of atmospheric $\mathrm{Hg}(0)$}

From 19 January to 8 February 2012 and from 5 to 20 February 2013 we observed $\mathrm{Hg}(0)$ depletion events. The mechanism seems however different from springtime AMDEs (see Sect. 3.1.1). While atmospheric $\mathrm{Hg}(0)$ concentrations dropped and remained low $\left(0.39 \pm 0.19 \mathrm{ng} \mathrm{m}^{-3}\right.$ from 19 January to 8 February $2012,0.41 \pm 0.21 \mathrm{ng} \mathrm{m}^{-3}$ from 5 to 20 February 2013) for several weeks (Figs. 3a, 6a and e), $\mathrm{O}_{3}$ showed no abnormal variability (Fig. $6 \mathrm{~d}$ and $\mathrm{h}$ ). These depletion events occurred as air masses stagnated over the Antarctic plateau (Fig. 4b and c) according to our FLEXPART simulations. This stagnation of air masses is confirmed

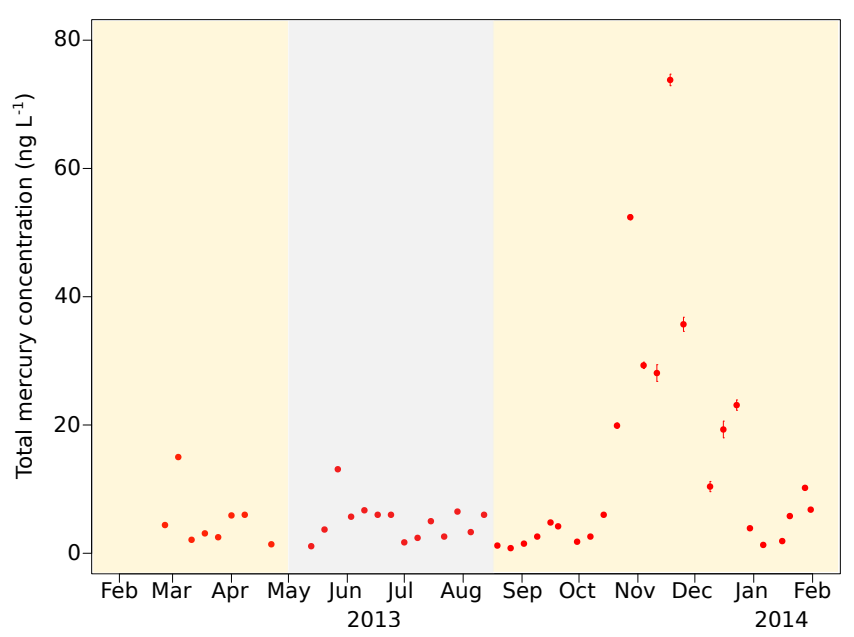

Figure 5. Total mercury concentration $\left(\mathrm{ng} \mathrm{L}^{-1}\right)$, along with standard errors, in surface snow samples collected weekly at Concordia Station from February 2013 to January 2014. Dark period (winter) highlighted in grey, sunlit period highlighted in yellow. Total mercury concentrations were elevated (up to $74 \mathrm{ng} \mathrm{L}^{-1}$ ) in NovemberDecember 2013 (summer). All samples were analyzed in replicates of three. Standard errors are frequently smaller than the width of the dots.

in 2013 (Fig. 6f and g) by a decrease of temperature at $10 \mathrm{~m}$ a.g.l. (from $-29 \pm 3{ }^{\circ} \mathrm{C}$ in January to $-43 \pm 4^{\circ} \mathrm{C}$ during the $\operatorname{Hg}(0)$ depletion event) and a low integrated water vapor $\left(0.40 \pm 0.13 \mathrm{~kg} \mathrm{~m}^{-2}\right.$ during the $\mathrm{Hg}(0)$ depletion event vs. $0.77 \pm 0.20 \mathrm{~kg} \mathrm{~m}^{-2}$ in January). In both 2012 and 2013 , depletions of $\mathrm{Hg}(0)$ ended when air masses started moving out of the plateau (Fig. $4 \mathrm{~d}$ and e).

While previous studies attributed high $\mathrm{Hg}$ (II) concentrations in the Antarctic summer to subsiding upper tropospheric air (Holmes et al., 2006; Brooks et al., 2008), potential emission sensitivities suggest that the depletions of $\mathrm{Hg}(0)$ reported here were unlikely concomitant with upper troposphere/lower stratosphere intrusions (Fig. 4b and c, PES at $4-10 \mathrm{~km})$. This is also confirmed by stable $\mathrm{O}_{3}$ mixing ratios. High altitude vertical profiles of $\mathrm{Hg}(0)$ should be carried out to rule out this hypothesis of subsiding upper tropospheric air. We suggest that these $\operatorname{Hg}(0)$ depletion events observed at Concordia Station result from processes occurring within the shallow boundary layer. Since $\mathrm{O}_{3}$ was not depleted during these events, $\operatorname{Hg}(0)$ depletion cannot be accounted for by bromine oxidation alone. FLEXPART simulations along with integrated water vapor and temperature measurements indicate that these $\mathrm{Hg}(0)$ depletion events occurred as air masses stagnated over the Antarctic plateau. As highlighted in the previous section, the oxidative capacity is high in summer on the plateau (Davis et al., 2001; Grannas et al., 2007; Eisele et al., 2008; Kukui et al., 2014). This air mass stagnation might favor an accumulation of oxidants within the shallow boundary layer ( $<300 \mathrm{~m}$ in average), leading to an oxidation of $\mathrm{Hg}(0)$ stronger than usual. 


\section{(c) $\mathrm{Hg}(\mathbf{0})$ diurnal cycle}
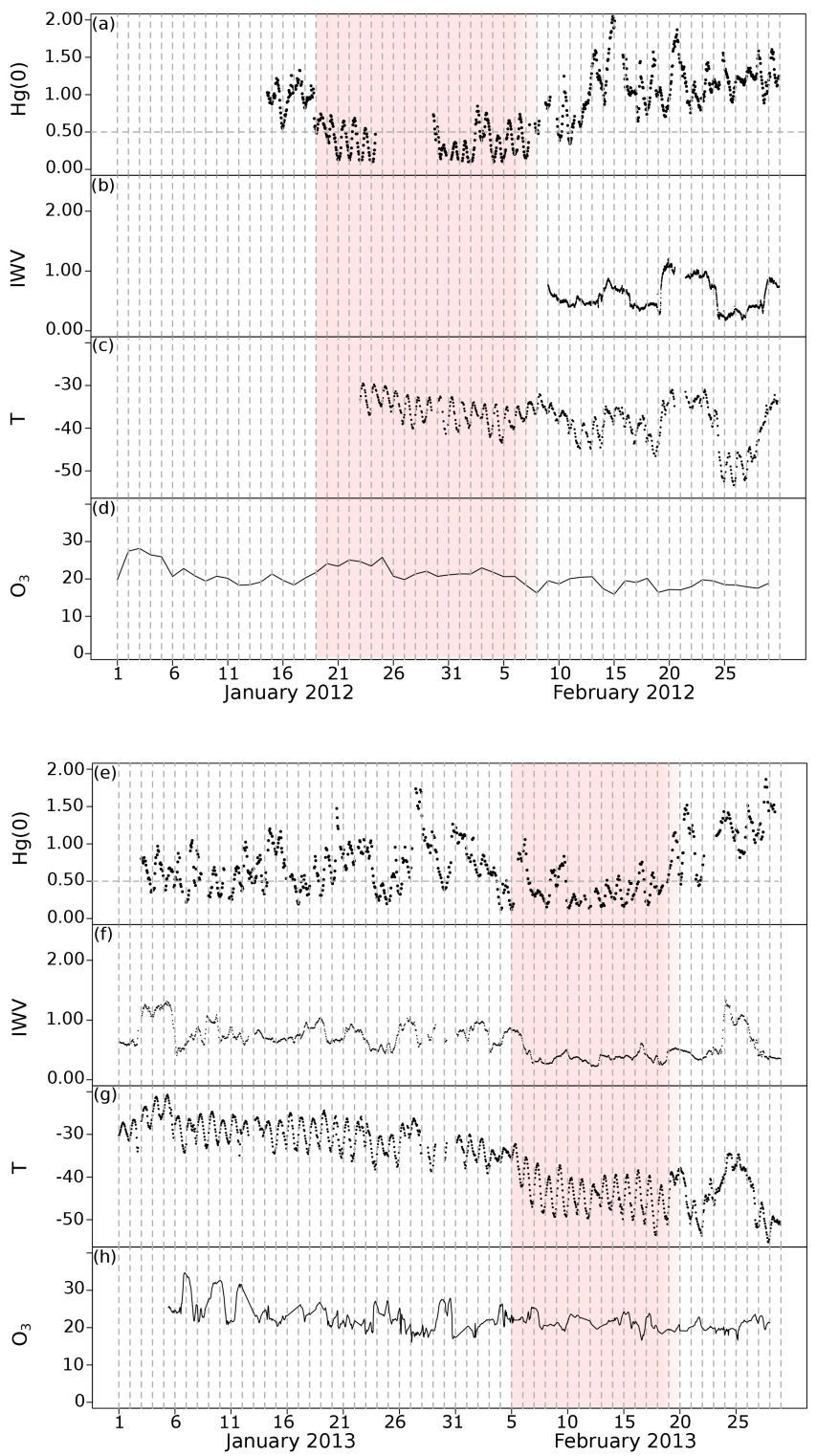

Figure 6. Top: January and February 2012 cycle of (a) hourly averaged $\mathrm{Hg}(0)$ concentrations (in $\mathrm{ng} \mathrm{m}^{-3}$ ) at $500 \mathrm{~cm}^{2}$ above the snow surface, (b) integrated water vapor (IWV, $\mathrm{kg} \mathrm{m}^{-2}$ ), (c) temperature (in ${ }^{\circ} \mathrm{C}$ ) at $10 \mathrm{~m}$ above ground level, and (d) ozone $\left(\mathrm{O}_{3}\right.$, daily mean) mixing ratios (ppbv). $\mathrm{Hg}(0)$ was low from 19 January to 8 February (period highlighted in red) while $\mathrm{O}_{3}$ showed no abnormal variability. Bottom: January and February 2013 cycle of the following: (e) hourly averaged $\mathrm{Hg}(0)$ concentrations (in $\mathrm{ng} \mathrm{m}^{-3}$ ) at $210 \mathrm{~cm}$ above the snow surface, (f) integrated water vapor (IWV, $\mathrm{kg} \mathrm{m}^{-2}$ ), (g) temperature (in ${ }^{\circ} \mathrm{C}$ ) at $10 \mathrm{~m}$ above ground level, and (h) ozone $\left(\mathrm{O}_{3}\right.$, hourly mean) mixing ratio (ppbv). $\mathrm{Hg}(0)$, IWV, and temperature were low from 5 to 20 February (period highlighted in red) while $\mathrm{O}_{3}$ showed no abnormal variability. Note that $\mathrm{Hg}(0)$ concentrations exhibited the same pattern at the three inlets of the meteorological tower from 5 to 20 February 2013.

Based on a week of measurements made at Concordia Station in January 2009, Dommergue et al. (2012) reported that atmospheric $\mathrm{Hg}(0)$ exhibited a significant daily cycle with maximal concentrations around noon. We show that this daily cycle occurred throughout the summer, with low atmospheric $\mathrm{Hg}(0)$ concentrations $\left(\sim 0.50 \mathrm{ng} \mathrm{m}^{-3}\right)$ when solar radiation was minimum and a maximum $\left(\sim 0.80 \mathrm{ng} \mathrm{m}^{-3}\right)$ around noon (Fig. 7a). Such a pronounced daily cycle has never been observed at other Antarctic stations (Dommergue et al., 2010; Pfaffhuber et al., 2012). Several studies showed that $\mathrm{Hg}(0)$ emission from the snowpack maximizes near midday (e.g., Steffen et al., 2002; Ferrari et al., 2005; Brooks et al., 2006; Faïn et al., 2007; Ferrari et al., 2008; Johnson et al., 2008). As suggested by Durnford and Dastoor (2011), the noon emission does not necessarily reflect maximum concentrations of cryospheric $\mathrm{Hg}(0)$ around midday $(\mathrm{Hg}(0)$ concentration peaked in the afternoon at $10 \mathrm{~cm}$ below the snow surface, see Sect. 3.2.1) and could be driven by ventilation generated by atmospheric thermal convection. Stable boundary layers are almost ubiquitous in polar regions due to radiation cooling (Anderson and Neff, 2008). However, convective boundary layers have been observed in summer at polar domes at Concordia Station (King et al., 2006) and Summit in Greenland (Cohen et al., 2007). Figure 7 displays the hourly mean variation of several parameters. As illustrated by Fig. 7c and d, and in agreement with earlier observations (Argentini et al., 2005; Pietroni et al., 2012; Argentini et al., 2013), there was a strong diurnal cycle in nearsurface temperature and wind speed in summer at Concordia Station. These observations are typical for locations where a convective boundary layer develops as a response to daytime heating (King et al., 2006), as can be seen in Fig. 7e. In a convective boundary layer, vertical mixing is enhanced during convective hours (Anderson and Neff, 2008), as shown in Fig. $7 \mathrm{f}$ and $\mathrm{g}$ by increasing values for the friction velocity $\left(u_{*}\right.$, indicative of the strength of the mixing processes in the surface layer; Neff et al., 2008) and the Eddy diffusivity $(K)$. Similarly, several studies highlighted that the atmospheric turbulence at Concordia Station in summer influences the vertical flux and concentration profiles of various atmospheric species (Legrand et al., 2009; Dommergue et al., 2012; Kerbrat et al., 2012; Frey et al., 2013).

In summary, the observed summertime $\mathrm{Hg}(0)$ diurnal cycle in ambient air might be due to a combination of factors: (i) the intense oxidation of $\operatorname{Hg}(0)$ in ambient air due to the high oxidative capacity on the plateau - as evidenced by low mean $\operatorname{Hg}(0)$ concentrations (see Sect. 3.2.1.a), (ii) subsequent $\mathrm{Hg}$ (II) deposition onto snowpack - as evidenced by elevated total mercury levels in surface snow samples (see Sect. 3.2.1.a), and (iii) emission of $\mathrm{Hg}(0)$ from the snowpack during convective hours. Figure 8 summarizes the processes that govern mercury exchange at the air-snow interface. Re- 
(a) $\mathrm{Hg}(0)$
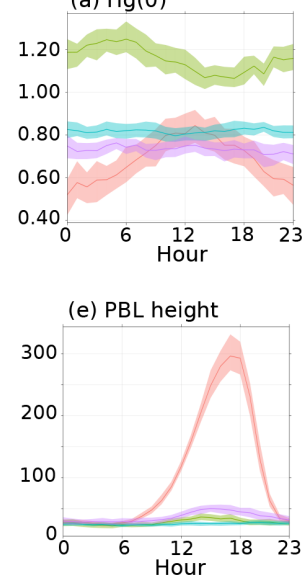

(b) SW
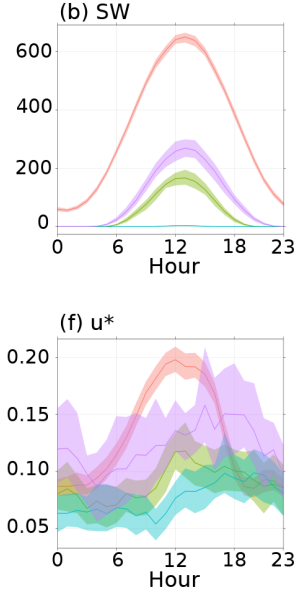

(c) Temperature
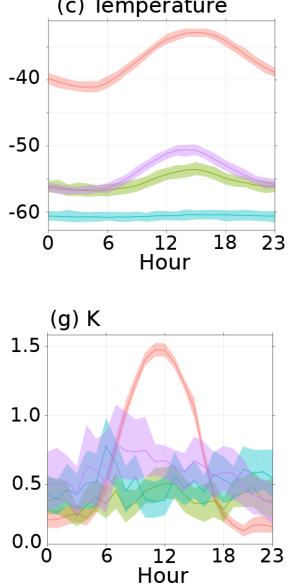

(d) WS
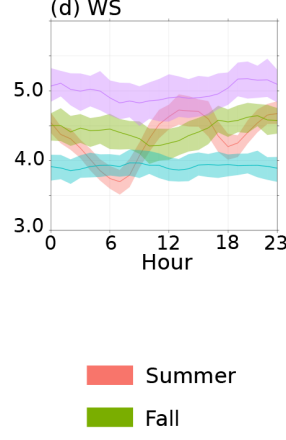

Winter

Spring

Figure 7. Hourly (local time) mean variation, along with the $95 \%$ confidence interval for the mean, of: (a) $\mathrm{Hg}(0)$ concentration (in ng $\mathrm{m}^{-3}$ ) at $25 \mathrm{~cm}$ above the snow surface, (b) downwelling shortwave $(\mathrm{SW})$ radiation (in $\mathrm{W} \mathrm{m}^{-2}$ ) according to the MAR model simulations, (c) temperature $\left(\right.$ in ${ }^{\circ} \mathrm{C}$ ) at $3 \mathrm{~m}$ above the snow surface, (d) wind speed at $3 \mathrm{~m}$ above the snow surface (in $\mathrm{m} \mathrm{s}^{-1}$ ), (e) planetary boundary layer (PBL) height (in $\mathrm{m}$ ) according to the MAR model simulations, (f) friction velocity $\left(u_{*}\right.$, in $\left.\mathrm{m} \mathrm{s}^{-1}\right)$, and (g) Eddy diffusivity $\left(K\right.$, in $\left.\mathrm{m}^{2} \mathrm{~s}^{-1}\right)$ in summer (red), fall (green), winter (blue), and spring (purple). Note that the hourly mean variation of $\operatorname{Hg}(0)$ concentration in summer is similar at the three inlets of the meteorological tower.

dox processes occurring within the snowpack are discussed in details in Sect. 3.2.

\subsubsection{Fall}

In fall, $\mathrm{Hg}(0)$ concentrations in ambient air no longer peaked around midday (Fig. 7a) and were in average $67 \%$ higher than during the summer, exceeding levels recorded at lower latitudes in the Southern Hemisphere (Slemr et al., 2015). In this period of the year, the boundary layer lowered to $\sim 50 \mathrm{~m}$ in average and no longer exhibited a pronounced diurnal cycle (Figs. 3c and 7e). We believe that the shallow boundary layer could cause $\mathrm{Hg}(0)$ concentrations in ambient air to build up to where they exceeded levels recorded at lower latitudes in the Southern Hemisphere because $\mathrm{Hg}(0)$ - emitted from the snowpack - was dispersed into a reduced volume of air, limiting the dilution. Similarly, $\mathrm{NO}_{x}$ mixing ratios are enhanced when the boundary layer is shallow (Neff et al., 2008; Frey et al., 2013). Elevated $\mathrm{Hg}(0)$ concentrations were also likely favored by the fact that oxidation in ambient air was weaker under lower solar radiation.

\subsubsection{Winter}

While stable concentrations were expected in winter given the absence of photochemistry, our observations reveal a 20 to $30 \%$ decrease of atmospheric $\mathrm{Hg}(0)$ concentrations from May to mid-August (Fig. 3a). Conversely, $\mathrm{Hg}(0)$ concentrations remained stable at Neumayer and Troll from late fall through winter (Ebinghaus et al., 2002; Pfaffhuber et al., 2012). This decreasing trend observed in winter might be due to several mechanisms, including gas-phase oxidation, heterogeneous reactions, or dry deposition of $\mathrm{Hg}(0)$.
Several studies suggested the involvement of nitrate radicals in the night-time oxidation of $\mathrm{Hg}(0)$ (Mao and Talbot, 2012; Peleg et al., 2015). However, as previously mentioned, Dibble et al. (2012) indicated that $\mathrm{NO}_{3}$ binds $\mathrm{Hg}(0)$ too weakly to initiate its oxidation in the gas phase. Another potential oxidant is $\mathrm{O}_{3}$, with this reactant reaching a maximum in the winter (Fig. 3d). However, according to some theoretical studies (e.g., Hynes et al., 2009), Reaction (R1) is unlikely to proceed as a homogeneous reaction. Several experimental studies confirmed the major product of Reaction (R1) to be solid mercuric oxide, $\mathrm{HgO}(\mathrm{s})$ and not $\mathrm{HgO}(\mathrm{g})$ (e.g., Pal and Ariya, 2004; Ariya et al., 2009), suggesting that pure gas-phase oxidation of elemental mercury by $\mathrm{O}_{3}$ may not occur in the atmosphere. However, Calvert and Lindberg (2005) proposed an alternative mechanism that would make this reaction potentially viable in the atmosphere (Subir et al., 2011). The reaction may start with the formation of a metastable $\mathrm{HgO}_{3}(\mathrm{~g})$ molecule which then decomposes to $\mathrm{OHgOO}(\mathrm{g})$ and thereafter transforms to $\mathrm{HgO}(\mathrm{s})$ and $\mathrm{O}_{2}(\mathrm{~g})$.

$\mathrm{Hg}(0)(\mathrm{g})+\mathrm{O}_{3}(\mathrm{~g}) \rightarrow \mathrm{HgO}(\mathrm{g})+\mathrm{O}_{2}(\mathrm{~g})$

As suggested by Subir et al. (2011), the influence of heterogeneous surfaces of water droplets, snow, ice, and aerosols should be taken into account when attempting to describe mercury chemistry in the atmosphere. O'Concubhair et al. (2012) showed that freezing an acidic solution containing nitrite or hydrogen peroxide can oxidize dissolved gaseous mercury in the dark. Nitrous acid and hydrogen peroxide are present on the Antarctic plateau (Huey et al., 2004; Hutterli et al., 2004). As suggested by Dommergue et al. (2012), similar processes could occur in the snow or on surface hoar at Concordia Station in winter. In 2013, the height of measure- 
(a) Summer: stable PBL

$$
\mathrm{T} \sim-40^{\circ} \mathrm{C}
$$

Free troposphere

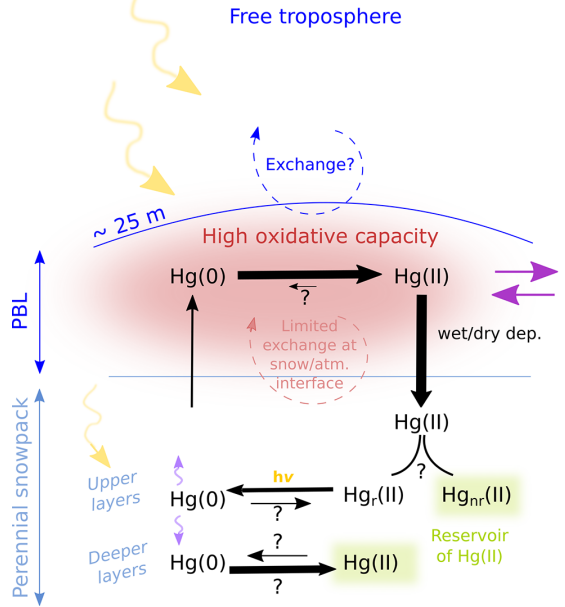

(c) Spring/Fall

$\mathrm{T} \sim-55^{\circ} \mathrm{C}$

Free troposphere

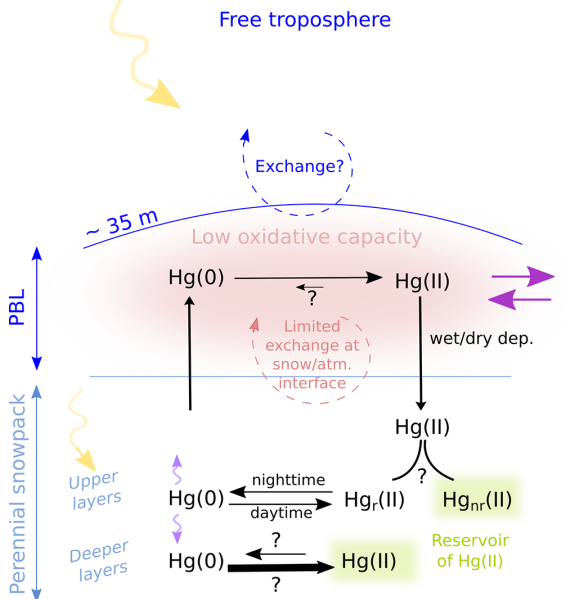

(b) Summer: convective PBL (midday)

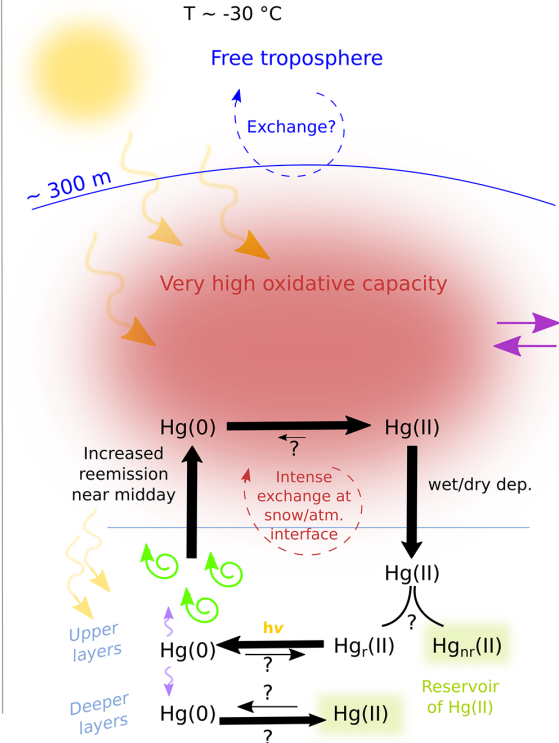

(d) Winter $\mathrm{T} \sim-60^{\circ} \mathrm{C}$

Free troposphere

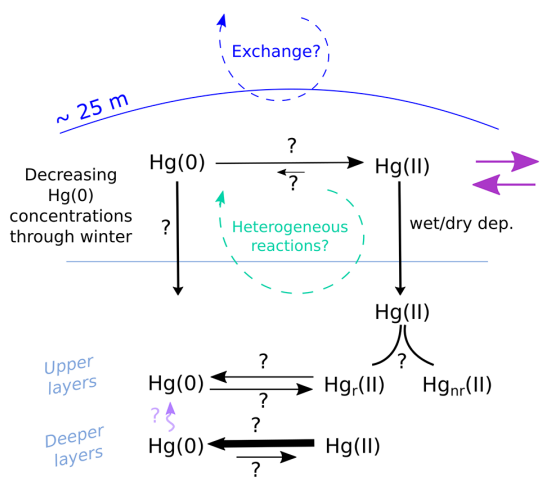

Perennial snowpack:

Upper layers: first $10 \mathrm{~cm}$

Deeper layers: below $50 \mathrm{~cm}$

$\mathrm{Hg}(\mathrm{II})$ : divalent mercury species (gaseous and/or particulate)

is diffusion

H.(II): reducible divalent mercury

$\mathrm{Hg}_{\mathrm{nr}}(\mathrm{II})$ : non reducible divalent mercury

ventilation

Figure 8. Schematic diagram illustrating the processes that govern the $\mathrm{Hg}(0)$ budget at Concordia Station (a) in summer under stable Planetary Boundary Layer (PBL) conditions, (b) in summer under convective PBL conditions, (c) in spring/fall, and (d) in winter. In summer, $\mathrm{Hg}(0)$ is intensely oxidized due to the high oxidative capacity of the boundary layer and a large amount of divalent mercury species deposit onto the snowpack. A fraction of deposited mercury can be reduced (the reducible pool, $\mathrm{Hg}_{\mathrm{r}}(\mathrm{II})$ ) in the upper layers of the snowpack and subsequently re-emitted to the atmosphere as $\mathrm{Hg}(0) . \mathrm{Hg}(0)$ emission from the snowpack maximizes near midday likely due to increased ventilation as a response to daytime heating. Oxidation of $\mathrm{Hg}(0)$ dominates in the deeper layers of the snowpack likely leading to the formation of a $\mathrm{Hg}$ (II) reservoir. In spring/fall, the balance of reduction and oxidation processes within the upper layers of the snowpack differs from summertime: oxidation dominates during the day, reduction at night. $\mathrm{In}$ winter, $\mathrm{Hg}(0)$ is produced in the deeper layers of the snowpack likely as a result of the reduction of $\mathrm{Hg}(\mathrm{II})$ species accumulated during the sunlit period. $\mathrm{Ambient} \mathrm{Hg}(0) \operatorname{concentrations}$ exhibit a 20 to $30 \%$ decrease through winter possibly due to dry deposition of $\operatorname{Hg}(0)$. 
ment had a significant influence on the decline over time of $\mathrm{Hg}(0)$ concentrations (ANCOVA test, $p$ value $<0.05$ ), with a steeper decrease at $25 \mathrm{~cm}$ than at $1070 \mathrm{~cm}$. Additionally, wintertime $\mathrm{Hg}(0)$ concentrations were significantly lower at $25 \mathrm{~cm}$ than at $1070 \mathrm{~cm}$ ( $p$ value $<0.05$, Mann-Whitney test). These results suggest that snowpack may act as a sink for mercury, enhancing the deposition rate due to heterogeneous reactions, through absorption of oxidation products, and/or physical sorption/condensation of $\mathrm{Hg}(0)$ on surface snow.

The observed declining trend could also be attributed to the dry deposition of $\mathrm{Hg}(0)$ onto the snowpack. The dry deposition velocity is defined as follows (Joffre, 1988), as the ratio between the deposition flux $F\left(\mathrm{ng} \mathrm{m}^{-2} \mathrm{~s}^{-1}\right)$ and the concentration $C\left(\mathrm{ng} \mathrm{m}^{-3}\right)$ :

$v_{\mathrm{d}}=\frac{F}{C}$.

Denoting the height of the boundary layer $h$ and the $\operatorname{Hg}(0)$ concentration at the beginning of winter $C_{0}$, the evolution of the concentration vs. time is thus given by the following ordinary differential equation:

$C=C_{0} e^{-\left(v_{\mathrm{d}} / h\right) t}$.

During winter $(t=107$ days $)$, the $\mathrm{Hg}(0)$ concentration gradually decreased from $C_{0} \sim 1.03 \mathrm{ng} \mathrm{m}^{-3}$ to $C \sim 0.73 \mathrm{ng} \mathrm{m}^{-3}$ at $25 \mathrm{~cm}$ above the snowpack, in a mixing layer of $25 \mathrm{~m}$ high. According to Eq. (3) the associated dry deposition velocity is $9.3 \times 10^{-5} \mathrm{~cm} \mathrm{~s}^{-1}$. This result is in very good agreement with dry deposition velocities reported for $\mathrm{Hg}(0)$ over snow (Cobbett et al., 2007; Zhang et al., 2009).

In spite of the observed decreasing trend of $\mathrm{Hg}(0)$ concentrations in ambient air, total mercury concentrations in surface snow samples did not significantly increase over time in winter (Fig. 5). Using a snow density of $300 \mathrm{~kg} \mathrm{~m}^{-3}$ a loss of $0.30 \mathrm{ng} \mathrm{m}^{-3}$ over a period of 3 months in a mixing layer of $25 \mathrm{~m}$ high would lead to a $2.5 \mathrm{ng} \mathrm{L}^{-1}$ increase in the first $\mathrm{cm}$ of the snowpack. Given the variability of chemical species deposition onto the snow surface, and the occurrence of either fresh snowfall or blowing snow, this $2.5 \mathrm{ng} \mathrm{L}^{-1}$ increase over a period of three months could not be detected in our weekly surface snow samples.

Despite the overall decreasing trend in winter, $\operatorname{Hg}(0)$ concentration exhibited abrupt increases when moist and warm air masses from lower latitudes occasionally reached Concordia Station. This is, for example, evidenced on 13 June 2012 by an increase of $0.25 \mathrm{ng} \mathrm{m}^{-3}$ of the $\mathrm{Hg}(0)$ concentration, an increase of temperature at $10 \mathrm{~m}$ a.g.l. from -63 to $-26^{\circ} \mathrm{C}$, and a high integrated water vapor column (Fig. 9).

\section{2 $\mathrm{Hg}(0) / \mathrm{Hg}(\mathrm{II})$ redox conversions within the snowpack}

The 2013 record of $\operatorname{Hg}(0)$ in the snow interstitial air (SIA) is displayed in Fig. 10. Figure 11 depicts the mean $\mathrm{Hg}(0)$ concentration at various heights above and below the snow surface (in the interstitial air of the snow) for all seasons.

\subsubsection{Sunlit period}

During the sunlit period (summer, spring/fall), $\mathrm{Hg}(0)$ concentration peaked in the upper layers of the snowpack and then decreased with depth, with levels in the SIA dropping below atmospheric values.

$\mathrm{Hg}(0)$ is generally produced in the upper layers of the snowpack - as the result of a photolytically initiated reduction of $\mathrm{Hg}$ (II) (Lalonde et al., 2003) - and diffuses upward and downward. According to our observations, $\mathrm{Hg}(0)$ concentration peaked at $\sim 10 \mathrm{~cm}$ below the snow surface (Fig. 11). Similarly, Brooks et al. (2008) reported $\mathrm{Hg}(0)$ concentrations peaking at a depth of $3 \mathrm{~cm}$ at South Pole. Below the top layer, the actinic flux decreases exponentially with depth (King and Simpson, 2001; Domine et al., 2008). The light penetration depth (e-folding depth) is the depth at which the actinic flux's magnitude is $1 / e$ of its incident value (Perovich, 2007). It is estimated that $\sim 85 \%$ of the photoreduction occurs in the top two $e$-folding depths (King and Simpson, 2001). At Concordia Station, the $e$-folding depth is $\sim 10 \mathrm{~cm}$ at $400 \mathrm{~nm}$ for the wind pack layers (France et al., 2011), which supports our observations. Reduced mercury can concurrently be reoxidized within the snowpack. Below the top layer, $\operatorname{Hg}(0)$ concentration in the SIA dropped with depth (Fig. 11) suggesting that oxidation dominated in the deepest layers - in good agreement with observations within the snowpack at Kuujjuarapik/Whapmagoostui, Québec, Canada (Dommergue et al., 2003) - leading to the formation of a $\mathrm{Hg}(\mathrm{II})$ reservoir.

The amount of $\operatorname{Hg}(0)$ emitted from the snowpack to the atmosphere (see Sect. 3.1.2.c) depends on the balance of reduction and oxidation processes within the upper layers of the snowpack (Durnford and Dastoor, 2011). Figure 12 depicts the hourly mean atmospheric and interstitial air $\mathrm{Hg}(0)$ concentrations. Our observations indicate that summertime $\mathrm{Hg}(0)$ concentration in the upper layers of the snowpack exhibited a diurnal cycle and peaked in the afternoon (Fig. 12a). Conversely, in spring/fall, $\operatorname{Hg}(0)$ concentration reached a maximum at night and a minimum near midday in the upper layers of the snowpack (Fig. 12b). The balance of reduction and oxidation processes within the upper layers of the snowpack suddenly shifted in summer. Similarly, Faïn et al. (2008) found that reduction dominated during summer and oxidation in spring in the upper layers of the snowpack at Summit, Greenland.

It is worth noting that $\mathrm{Hg}(0)$ concentration in the SIA was occasionally very high. For instance, on 24 February 2013, $\mathrm{Hg}(0)$ concentration reached $3.00 \mathrm{ng} \mathrm{m}^{-3}$ at a depth of $10 \mathrm{~cm}$. During this event, ice precipitation was observed at Concordia Station with depolarization values greater than $30 \%$ (data not shown). This suggests that the presence of ice crystals could enhance the dry deposition of $\mathrm{Hg}$ (II) species onto the snow surface leading to increased $\operatorname{Hg}(0)$ formation in the upper layers of the snowpack. Indeed, due to an elevated specific surface area, mercury-capture efficiency of ice 


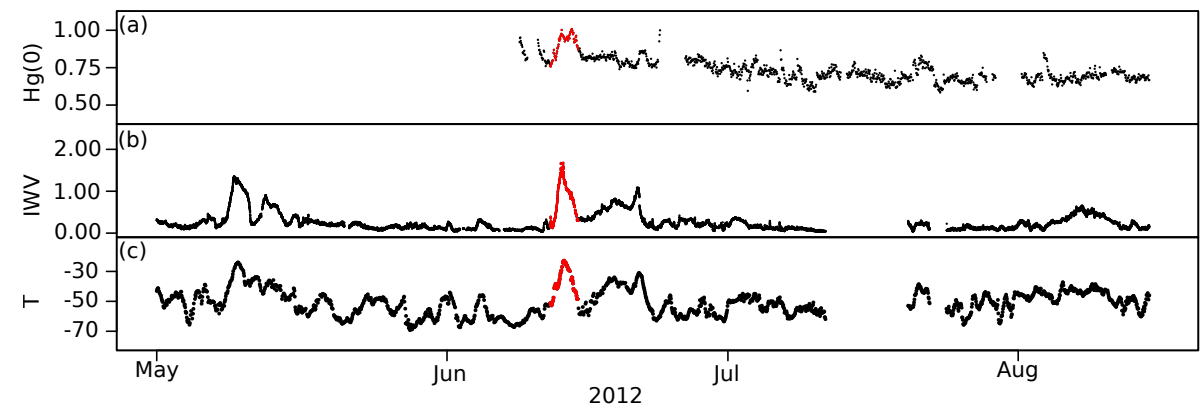

Figure 9. Year 2012 wintertime record of (a) hourly averaged $\mathrm{Hg}(0)$ concentrations (in $\mathrm{ng} \mathrm{m}^{-3}$ ) at $500 \mathrm{~cm}$ above the snow surface, (b) integrated water vapor (IWV, $\mathrm{kg} \mathrm{m}^{-2}$ ), and (c) temperature $\left(T,{ }^{\circ} \mathrm{C}\right)$ at $10 \mathrm{~m}$ above ground level. $\mathrm{Hg}(0)$, temperature, and IWV increased from 12 to 15 June (in red) suggesting transport of moist and warm air masses originating from lower latitudes.

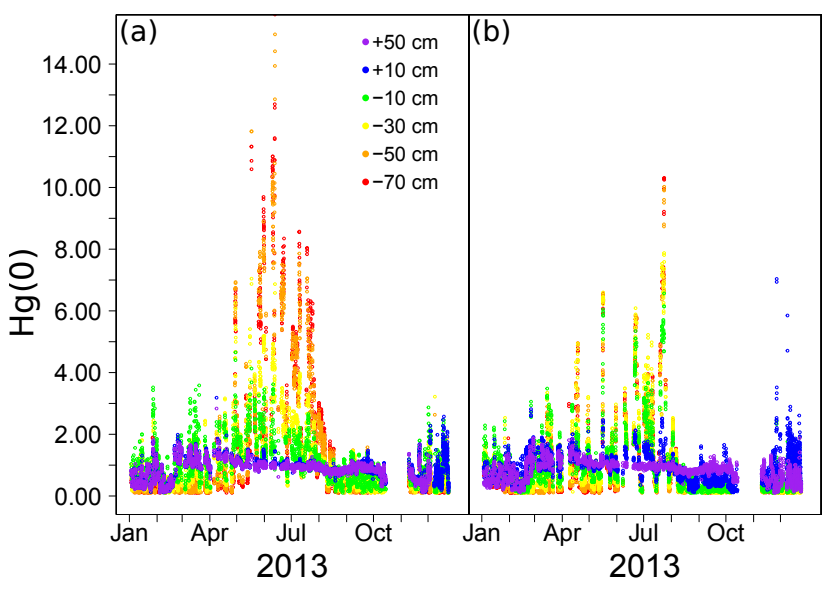

Figure 10. Annual variation of hourly averaged $\operatorname{Hg}(0)$ concentrations (in $\mathrm{ng} \mathrm{m}^{-3}$ ) in the snow interstitial air collected at the various inlets of the two snow towers: (a) snow tower \#1, (b) snow tower \#2. Note that we regularly experienced technical problems on snow tower \#2 leading to missing values.

crystals is high (Douglas et al., 2008). Unfortunately, due to a low sampling frequency of surface snow samples (weekly), total mercury concentrations cannot be used to study further the relationship between the occurrence of ice precipitation events and dry deposition of mercury species.

\subsubsection{Winter}

Contrarily to the sunlit period, $\operatorname{Hg}(0)$ concentration increased with depth in the SIA in winter (Figs. 10 and 11). The average $\mathrm{Hg}(0)$ concentration amounted to $3.60 \mathrm{ng} \mathrm{m}^{-3}$ at a depth of $70 \mathrm{~cm}$ and was observed at a temperature of about $-60^{\circ} \mathrm{C}$ and not related to any change in atmospheric composition. Our observations are in agreement with earlier studies indicating that reduction of $\mathrm{Hg}$ (II) species is possible in the dark (Ferrari et al., 2004; Faïn et al., 2007; Ferrari et al., 2008). The production of $\operatorname{Hg}(0)$ might be due to the reduction of $\mathrm{Hg}$ (II) species accumulated in the deepest layers of the snow-

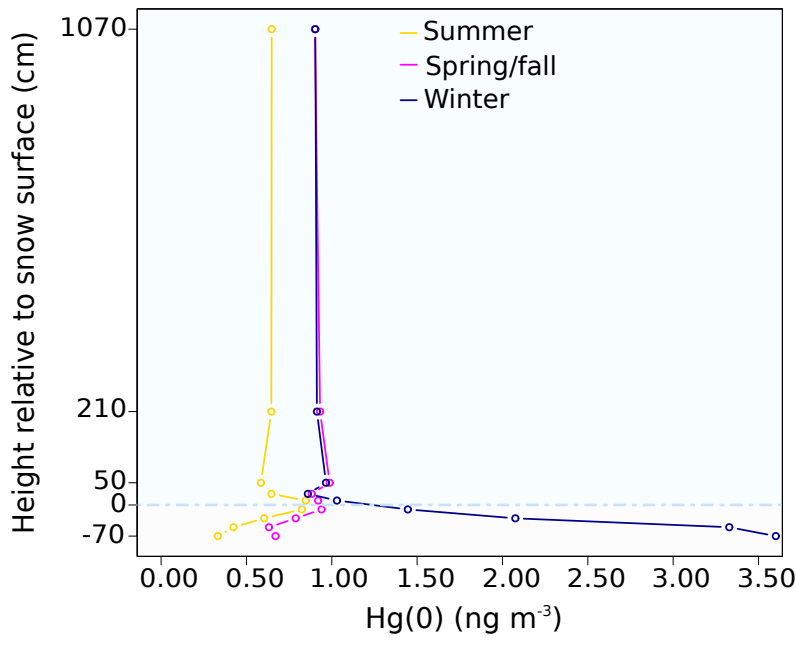

Figure 11. Mean $\mathrm{Hg}(0)$ concentration $\left(\mathrm{ng} \mathrm{m}^{-3}\right)$ measured at various heights above and below the snow surface $(\mathrm{cm})$ at Concordia Station in summer (yellow), spring/fall (purple), and winter (dark blue) The horizontal light blue dashed line represents the snow surface.

pack during the sunlit period (see Sect. 3.2.1). This shift from oxidation to reduction in the deepest layers of the snowpack at the beginning of winter remains unexplained.

\section{Implications on a continental scale}

Depletion events of atmospheric $\mathrm{Hg}(0)$ that have been observed in the Arctic and at various coastal Antarctic stations have been associated with $\mathrm{O}_{3}$ depletions, where $\mathrm{Hg}(0)$ and $\mathrm{O}_{3}$ concentrations are positively correlated (Simpson et al., 2007). Increases in both $\mathrm{Hg}(\mathrm{II})$ and $\mathrm{Hg}(\mathrm{p})$ have been reported in conjunction with decreases of $\mathrm{Hg}(0)$ (Lu et al., 2001; Lindberg et al., 2002; Aspmo et al., 2005). Conversely, low $\mathrm{Hg}(0)$ concentrations that were not correlated or anti-correlated with $\mathrm{O}_{3}$ were observed at Neumayer and Troll (Temme et al., 2003; Pfaffhuber et al., 2012), while elevated $\mathrm{Hg}$ (II) concen- 


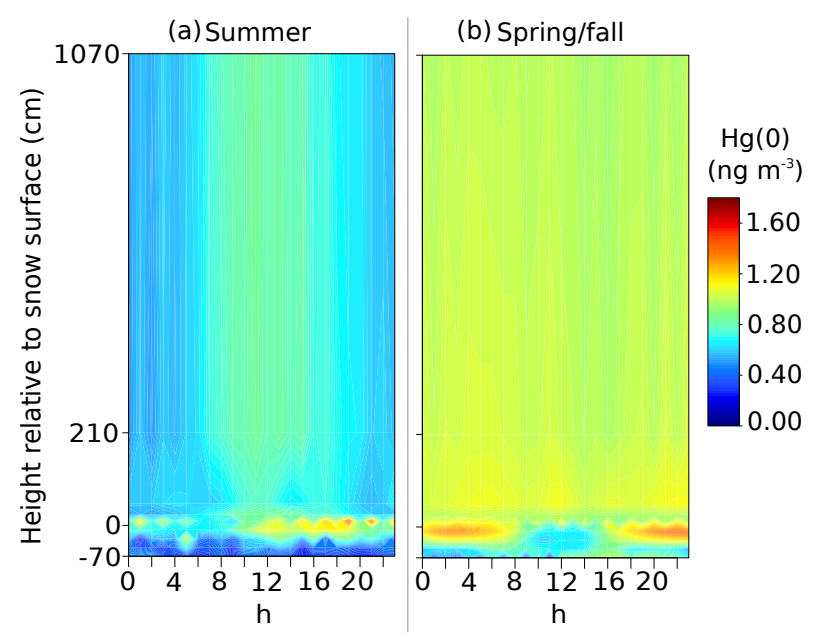

Figure 12. Hourly (local time) mean atmospheric and interstitial air $\mathrm{Hg}(0)$ concentrations in (a) summer, and (b) spring/fall. The vertical axis is the height of measurement relative to the snow surface (in $\mathrm{cm}$ ). Color contours show $\mathrm{Hg}(0)$ concentrations (in $\mathrm{ng} \mathrm{m}^{-3}$ ). Concentrations at 25,210 , and $1070 \mathrm{~cm}$ above the snow surface were acquired on the meteorological tower while concentrations at 50 , $10,-10,-30,-50$, and $-70 \mathrm{~cm}$ were collected on snow tower \#1. Data were cubic spline interpolated using software R.

trations (up to $0.33 \mathrm{ng} \mathrm{m}^{-3}$ ) were recorded at Terra Nova Bay in the absence of $\mathrm{Hg}(0) / \mathrm{O}_{3}$ depletion (Sprovieri et al., 2002). The intense oxidation of $\mathrm{Hg}(0)$ in summer (see Sect. 3.1.2.a) and multi-day $\mathrm{Hg}(0)$ depletion events observed at Concordia Station in January/February (see Sect. 3.1.2.b) are expected to result in the build-up of an inland atmospheric reservoir enriched in $\operatorname{Hg}$ (II) and depleted in $\operatorname{Hg}(0)$ in the summer. Due to strong katabatic winds flowing out from the Antarctic Plateau - generated by the negative buoyant force that develops in the stable cooled layer along the ice sheet slopes (Gallée and Pettré, 1998) -, a fraction of this inland atmospheric reservoir can be transported toward the coastal margin. The influence of the flows from the Antarctic plateau on coastal locations varies depending on the location. As demonstrated by Parish and Bromwich $(1987,2007)$, the volume of air moving off inland Antarctica toward the coastal margin displays significant spatial variability due to the topographic slope and orientation of the underlying ice sheets. Northward transport of air from the plateau is enhanced in a few locations called confluence zones - e.g., the broad region upslope from the Ross Ice Shelf at $175^{\circ} \mathrm{E}$ and the area near Adélie Land at $142^{\circ} \mathrm{E}$ - but can be sporadically observed elsewhere explaining the aforementioned observations at Neumayer, Troll, or Terra Nova Bay. Monitoring atmospheric mercury at a coastal station situated close to a confluence zone could provide new insights regarding the extent of the transport of reactive air masses from the Antarctic plateau. This topic is addressed in a companion paper (Angot et al., 2016). The Antarctic continent shelters unconventional atmospheric pathways of mercury reactivity both in winter and in summer. Its role should be taken into account in the modeling of the global geochemical cycle of mercury.

\section{Conclusion}

Mean summertime atmospheric $\mathrm{Hg}(0)$ concentration was $\sim 25 \%$ lower compared to values recorded at other Antarctic stations at the same period of the year, suggesting an intense oxidation of atmospheric $\mathrm{Hg}(0)$ within the shallow boundary layer as a result of the high oxidative capacity of the Antarctic plateau atmosphere in this period of the year. This hypothesis is further supported by high total mercury concentrations in surface snow samples measured at the station (up to $74 \mathrm{ng}$ $\mathrm{L}^{-1}$ ). Our results confirm short-term observations by Brooks et al. (2008) and Dommergue et al. (2012) of chemical exchange at the air-snow interface. During the sunlit period, $\mathrm{Hg}(0)$ concentration peaked in the upper layers of the snowpack. Summertime $\operatorname{Hg}(0)$ concentration in ambient air exhibited a pronounced diurnal cycle likely due to large emissions from the snowpack as a response to daytime snowpack ventilation. Our observations also reveal a decrease of atmospheric mercury concentrations in winter ( $24 \mathrm{~h}$ darkness) possibly due to the dry deposition of $\mathrm{Hg}(0)$. Interestingly, this decreasing trend has never been observed elsewhere. Additionally, $\operatorname{Hg}(0)$ concentrations increased with depth in the snow interstitial air in winter likely due to a dark reduction of $\mathrm{Hg}(\mathrm{II})$ species accumulated within the snowpack during the sunlit period. Finally, we reveal the occurrence of multiday to weeklong depletion events of $\mathrm{Hg}(0)$ in ambient air in summer, that are not associated with depletion of $\mathrm{O}_{3}$, and likely result from a stagnation of air masses on the plateau triggering an accumulation of oxidants in the shallow boundary layer. This behavior is radically different from what is usually observed in the Arctic where only mercury depletion events that were associated with $\mathrm{O}_{3}$ depletion (and with a $\mathrm{Hg}(0) / \mathrm{O}_{3}$ correlation) have been highlighted so far. According to observations at coastal Antarctic stations (see Sect. 4), the reactivity observed at Concordia Station can be transported on a continental scale by strong katabatic winds. Our understanding of the atmospheric mercury chemistry on the Antarctic plateau is currently limited by the lack of continuous halogens measurements. Our findings point out new directions for future kinetic, observational, and modeling studies.

\section{Data availability}

Mercury data reported in this paper are available upon request at http://sdi.iia.cnr.it/geoint/publicpage/GMOS/gmos_ historical.zul (GMOS, 2016). 
Acknowledgements. We thank A. Barbero and the rest of the overwintering crew: S. Aubin, C. Lenormant, and R. Jacob. We also gratefully acknowledge M. Barret for the development of a QA/QC software program, L. Bonato for the analysis of total mercury in surface snow samples, D. Liptzin for the calculation of the Obukhov length and friction velocity, M. Legrand for the 2012 ozone data, C. Genthon for the meteorological data, E. Vignon for helpful discussion, and B. Jourdain and X. Faïn for their help in the field. This work contributed to the EU-FP7 project Global Mercury Observation System (GMOS - www.gmos.eu) and has been supported by a grant from Labex OSUG@2020 (Investissements d'avenir - ANR10 LABX56), and the Institut Universitaire de France. Boris Quennehen and Philippe Ricaud acknowledge ANR CLIMSLIP and HAMSTRAD Program 910, respectively. Logistical and financial support was provided by the French Polar Institute IPEV (Program 1028, GMOstral and Program 1011, SUNITEDC), and a grant from the U.S. National Science Foundation (NSF, PLR\#1142145). Computing resources for FLEXPART simulations were provided by the IPSL CICLAD/CLIMSERV mesocenter. Meteorological data were obtained thanks to LEFE/IMAGO programs CLAPA and GABLS4, IPEV program CALVA/1013, and Observatoire des Sciences de l'Univers de Grenoble (GLACIOCLIM observatory).

Edited by: R. Ebinghaus

\section{References}

Anderson, P. S. and Neff, W. D.: Boundary layer physics over snow and ice, Atmos. Chem. Phys., 8, 3563-3582, doi:10.5194/acp-83563-2008, 2008.

Angot, H., Barret, M., Magand, O., Ramonet, M., and Dommergue, A.: A 2-year record of atmospheric mercury species at a background Southern Hemisphere station on Amsterdam Island, Atmos. Chem. Phys., 14, 11461-11473, doi:10.5194/acp14-11461-2014, 2014.

Angot, H., Dion, I., Vogel, N., Legrand, M., Magand, O., and Dommergue, A.: Multi-year record of atmospheric mercury at Dumont d'Urville, East Antarctic coast: continental outflow and oceanic influences, Atmos. Chem. Phys., 16, 8265-8279, doi:10.5194/acp-16-8265-2016, 2016.

Argentini, S., Viola, A., Sempreviva, A. M., and Petenko, I.: Summer boundary-layer height at the plateau site of Dome C, Antarctica, Bound.-Lay. Meteorol., 115, 409-422, 2005.

Argentini, S., Petenko, I., Viola, A., Mastrantonio, G., Pietroni, I., Casasanta, G., Aristidi, E., and Ghenton, C.: The surface layer observed by a high-resolution sodar at Dome C, Antarctica, Annals of geophysics, 56, F0557, doi:10.4401/ag-6347, 2013.

Ariya, P. A., Peterson, K., Snider, G., and Amyot, M.: Mercury chemical transformation in the gas, aqueous and heterogeneous phases: state-of-the-art science and uncertainties, in: Mercury fate and transport in the global atmosphere, edited by: Pirrone, N. and Mason, R. P., Springer, New York, USA, 2009.

Aspmo, K., Gauchard, P.-A., Steffen, A., Temme, C., Berg, T., Bahlmann, E., Banic, C., Dommergue, A., Ebinghaus, R., Ferrari, C., Pirrone, N., Sprovieri, F., and Wibetoe, G.: Measurements of atmospheric mercury species during an international study of mercury depletion events at Ny-Ålesund, Svalbard, spring 2003. How reproductible are our present methods?, Atmos. Environ., 39, 7607-7619, 2005.

Bloom, N. S. and Fitzgerald, W. F.: Determination of volatile mercury species at the picogram level by low temperature gas chromatography with cold-vapor atomic fluorescence detection, Anal. Chim. Acta, 208, 151-161, 1988.

Bocquet, F., Helmig, D., and Oltmans, S. J.: Ozone in interstitial air of the mid-latituden seasonal snowpack at Niwot Ridge, Colorado, Arct., Antarct. Alp. Res., 39, 375-387, 2007.

Brooks, S., Saiz-Lopez, A., Skov, H., Lindberg, S. E., Plane, J. M. C., and Goodsite, M. E.: The mass balance of mercury in the springtime arctic environment, Geophys. Res. Lett., 33, L13812, doi:10.1029/2005GL025525, 2006

Brooks, S. B., Arimoto, R., Lindberg, S. E., and Southworth, G.: Antarctic polar plateau snow surface conversion of deposited oxidized mercury to gaseous elemental mercury with fractional long-term burial, Atmos. Environ., 42, 2877-2884, 2008.

Calvert, J. G. and Lindberg, S. E.: Mechanisms of mercury removal by $\mathrm{O}_{3}$ and $\mathrm{OH}$ in the atmosphere, Atmos. Environ., 39, 33553367, 2005.

Cobbett, F. D., Steffen, A., Lawson, G., and Van Heyst, B. J.: GEM fluxes and atmospheric mercury concentrations (GEM, RGM and $\operatorname{Hg}(\mathrm{p}))$ in the Canadian Arctic at Alert, Nunavut, Canada (February-June 2005), Atmos. Environ., 41, 6527-6543, doi:10.1016/j.atmosenv.2007.04.033, 2007.

Cohen, L., Helmig, D., Neff, W. D., Grachev, A. A., and Fairall, C. W.: Boundary-layer dynamics and its influence on atmospheric chemistry at Summit, Greenland, Atmos. Environ., 41, 50445060, 2007.

D’Amore, F., Bencardino, M., Cinnirella, S., Sprovieri, F., and Pirrone, N.: Data quality through a web-based QA/QC system: implementation for atmospheric mercury data from the Global Mercury Observation System, Environmental Science: Processes \& Impacts, 17, 1482-1491, 2015.

Davis, D., Nowak, J. B., Chen, G., Buhr, M., Arimoto, R., Hogan, A., Eisele, F., Mauldin, L., Tanner, D., Shetter, R., Lefer, B., and McMurry, P.: Unexpected high levels of NO observed at South Pole, Geophys. Res. Lett., 28, 3625-3628, 2001.

Dibble, T. S., Zelie, M. J., and Mao, H.: Thermodynamics of reactions of $\mathrm{ClHg}$ and $\mathrm{BrHg}$ radicals with atmospherically abundant free radicals, Atmos. Chem. Phys., 12, 10271-10279, doi:10.5194/acp-12-10271-2012, 2012.

Domine, F., Albert, M., Huthwelker, T., Jacobi, H.-W., Kokhanovsky, A. A., Lehning, M., Picard, G., and Simpson, W. R.: Snow physics as relevant to snow photochemistry, Atmos. Chem. Phys., 8, 171-208, doi:10.5194/acp-8-171-2008, 2008.

Dommergue, A., Ferrari, C. P., Gauchard, P.-A., and Boutron, C. F.: The fate of mercury species in a sub-arctic snowpack during snowmelt, Geophys. Res. Lett., 30, 1621, doi:10.1029/2003GL017308, 2003.

Dommergue, A., Sprovieri, F., Pirrone, N., Ebinghaus, R., Brooks, S., Courteaud, J., and Ferrari, C. P.: Overview of mercury measurements in the Antarctic troposphere, Atmos. Chem. Phys., 10, 3309-3319, doi:10.5194/acp-10-3309-2010, 2010.

Dommergue, A., Barret, M., Courteaud, J., Cristofanelli, P., Ferrari, C. P., and Gallée, H.: Dynamic recycling of gaseous elemental mercury in the boundary layer of the Antarctic Plateau, 
Atmos. Chem. Phys., 12, 11027-11036, doi:10.5194/acp-1211027-2012, 2012.

Douglas, T. A., Sturm, M., Simpson, W. R., Blum, J. D., AlvarezAviles, L., Keeler, G. J., Perovich, D. K., Biswas, A., and Johnson, K.: Influence of snow and ice crystal formation and accumulation on mercury deposition to the Arctic, Environ. Sci. Technol., 42, 1542-1551, 2008.

Driscoll, C. T., Mason, R. P., Chan, H. M., Jacob, D. J., and Pirrone, N.: Mercury as a global pollutant: sources, pathways, and effects, Environ. Sci. Technol., 47, 4967-4983, 2013.

Durnford, D. and Dastoor, A.: The behavior of mercury in the cryosphere: a review of what we know from observations, J. Geophys. Res., 116, D06305, doi:10.1029/2010JD014809, 2011.

Ebinghaus, R., Kock, H. H., Temme, C., Einax, J. W., Löwe, A. G., Richter, A., Burrows, J. P., and Schroeder, W. H.: Antarctic springtime depletion of atmospheric mercury, Environ. Sci. Technol., 36, 1238-1244, 2002.

Eisele, F., Davis, D. D., Helmig, D., Oltmans, S. J., Neff, W., Huey, G., Tanner, D., Chen, G., Crawford, J. H., Arimoto, R., Buhr, M., Mauldin, L., Hutterli, M., Dibb, J., Blake, D., Brooks, S. B., Johnson, B., Roberts, J. M., Wang, Y., Tan, D., and Flocke, F.: Antarctic tropospheric chemistry (ANTCI) 2003 overview, Atmos. Environ., 2008, 2749-2761, 2008.

Faïn, X., Grangeon, S., Bahlmann, E., Fritsche, J., Obrist, D., Dommergue, A., Ferrari, C., Cairns, W., Ebinghaus, R., Barbante, C., Cescon, P., and Boutron, C. F.: Diurnal production of gaseous mercury in the alpine snowpack before snowmelt, J. Geophys. Res., 112, D21311, doi:10.1029/2007JD008520, 2007.

Faïn, X., Ferrari, C. P., Dommergue, A., Albert, M., Battle, M., Arnaud, L., Barnola, J.-M., Cairns, W., Barbante, C., and Boutron, C.: Mercury in the snow and firn at Summit Station, Central Greenland, and implications for the study of past atmospheric mercury levels, Atmos. Chem. Phys., 8, 3441-3457, doi:10.5194/acp-8-3441-2008, 2008.

Ferrari, C. P., Dommergue, A., Boutron, C. F., Skov, H., Goodsite, M. E., and Jensen, B.: Nighttime production of elemental gaseous mercury in interstitial air of snow at Station Nord, Greenland, Atmos. Environ., 38, 2727-2735, 2004.

Ferrari, C. P., Gauchard, P.-A., Aspmo, K., Dommergue, A., Magand, O., Bahlmann, E., Nagorski, S., Temme, C., Ebinghaus, R., Steffen, A., Banic, C., Berg, T., Planchon, F., Barbante, C., Cescon, P., and Boutron, C. F.: Snow-to-air exchanges of mercury in an arctic seasonal snowpack in Ny-Alesund, Svalbard, Atmos. Environ., 39, 7633-7645, 2005.

Ferrari, C. P., Padova, C., Faïn, X., Gauchard, P.-A., Dommergue, A., Aspmo, K., Berg, T., Cairns, W., Barbante, C., Cescon, P., Kaleschke, L., Richter, A., Wittrock, F., and Boutron, C. F.: Atmospheric mercury depletion event study in Ny-Alesund (Svalbard) in spring 2005. Deposition and transformation of $\mathrm{Hg}$ in surface snow during springtime, Sci. Total Environ., 397, 167-177, 2008.

Fitzgerald, W. F. and Gill, G. A.: Subnanogram determination of mercury by two-stage gold amalgamation and gas detection applied to atmospheric analysis, Anal. chem., 51, 1714-1720, 1979.

France, J. L., King, M. D., Frey, M. M., Erbland, J., Picard, G., Preunkert, S., MacArthur, A., and Savarino, J.: Snow optical properties at Dome C (Concordia), Antarctica; implications for snow emissions and snow chemistry of reactive nitrogen, At- mos. Chem. Phys., 11, 9787-9801, doi:10.5194/acp-11-97872011, 2011.

Frey, M. M., Brough, N., France, J. L., Anderson, P. S., Traulle, O., King, M. D., Jones, A. E., Wolff, E. W., and Savarino, J.: The diurnal variability of atmospheric nitrogen oxides (NO and $\mathrm{NO}_{2}$ ) above the Antarctic Plateau driven by atmospheric stability and snow emissions, Atmos. Chem. Phys., 13, 3045-3062, doi:10.5194/acp-13-3045-2013, 2013.

Frey, M. M., Roscoe, H. K., Kukui, A., Savarino, J., France, J. L., King, M. D., Legrand, M., and Preunkert, S.: Atmospheric nitrogen oxides ( $\mathrm{NO}$ and $\mathrm{NO}_{2}$ ) at Dome $\mathrm{C}$, East Antarctica, during the OPALE campaign, Atmos. Chem. Phys., 15, 7859-7875, doi:10.5194/acp-15-7859-2015, 2015.

Gallée, H. and Gorodetskaya, I. V.: Validation of a limited area model over Dome C, Antarctic Plateau, during winter, Clim. Dynam., 34, 61-72, 2010.

Gallée, H. and Pettré, P.: Dynamical constraints on katabatic wind cessation in Adélie Land, Antarctica, J. Atmos. Sci., 55, 17551770, 1998.

Gallée, H., Preunkert, S., Argentini, S., Frey, M. M., Genthon, C., Jourdain, B., Pietroni, I., Casasanta, G., Barral, H., Vignon, E., Amory, C., and Legrand, M.: Characterization of the boundary layer at Dome $\mathrm{C}$ (East Antarctica) during the OPALE summer campaign, Atmos. Chem. Phys., 15, 62256236, doi:10.5194/acp-15-6225-2015, 2015.

Genthon, C., Town, M. S., Six, D., Favier, V., Argentini, S., and Pellegrini, A.: Meteorological atmospheric boundary layer measurements and ECMWF analyses during summer at Dome C, Antarctica, J. Geophys. Res., 115, D05104, doi:10.1029/2009JD012741, 2010.

Genthon, C., Six, D., Gallée, H., Grigioni, P., and Pellegrini, A.: Two years of atmospheric boundary layer observations on a 45$\mathrm{m}$ tower at Dome C on the Antarctic plateau, J. Geophys. Res.Atmos., 118, 3218-3232, 2013.

GMOS: Land-based monitoring sites, available at: http://sdi.iia. cnr.it/geoint/publicpage/GMOS/gmos_historical.zul, last access: 27 Februrary 2016.

Goodsite, M. E., Plane, J. M. C., and Skov, H.: A theoretical study of the oxidation of $\mathrm{Hg}^{0}$ to $\mathrm{HgBr}_{2}$ in the troposphere, Environ. Sci. Technol., 38, 1772-1776, 2004.

Grannas, A. M., Jones, A. E., Dibb, J., Ammann, M., Anastasio, C., Beine, H. J., Bergin, M., Bottenheim, J., Boxe, C. S., Carver, G., Chen, G., Crawford, J. H., Dominé, F., Frey, M. M., Guzmán, M. I., Heard, D. E., Helmig, D., Hoffmann, M. R., Honrath, R. E., Huey, L. G., Hutterli, M., Jacobi, H. W., Klán, P., Lefer, B., McConnell, J., Plane, J., Sander, R., Savarino, J., Shepson, P. B., Simpson, W. R., Sodeau, J. R., von Glasow, R., Weller, R., Wolff, E. W., and Zhu, T.: An overview of snow photochemistry: evidence, mechanisms and impacts, Atmos. Chem. Phys., 7, 43294373, doi:10.5194/acp-7-4329-2007, 2007.

Hedgecock, I. M. and Pirrone, N.: Chasing quicksilver: modeling the atmospheric lifetime of $\mathrm{Hg}(0)$ in the marine boundary layer at various latitudes, Environ. Sci. Technol., 38, 69-76, 2004.

Hoegstroem, U.: Non-dimensional wind and temperature profiles in the atmosphere surface layer: a re-evaluation, Bound.-Lay. Meteorol., 42, 55-78, 1988.

Holmes, C. D., Jacob, D. J., and Yang, X.: Global lifetime of elemental mercury against oxidation by atomic bromine 
in the free troposphere, Geophys. Res. Lett., 33, L20808, doi:10.1029/2006GL027176, 2006.

Huey, L. G., Tanner, D. J., Slusher, D. L., Dibb, J. E., Arimoto, R., Chen, G., Davis, D., Buhr, M. P., Nowak, J. B., Mauldin, L., Eisele, F. L., and Kosciuch, E.: CIMS measurements of $\mathrm{HNO}_{3}$ and $\mathrm{SO}_{2}$ at the South Pole during ISCAT 2000, Atmos. Environ., 38, 5411-5421, 2004.

Hutterli, M. A., McConnell, J. R., Chen, G., Bales, R. C., Davis, D. D., and Lenschow, D. H.: Formaldehyde and hydrogen peroxide in air, snow and intersitial air at South Pole, Atmos. Environ., 38, 5439-5450, 2004.

Hynes, A. J., Donohoue, D. L., Goodsite, M. E., and Hedgecock, I. M.: Our current understanding of major chemical and physical processes affecting mercury dynamics in the atmosphere and at the air-water/terrestrial interfaces, in: Mercury fate and transport in the global atmosphere, edited by: Pirrone, N., and Mason, R. P., Springer, New York, USA, 427-457, 2009.

Joffre, S. M.: Modelling the dry deposition velocity of highly soluble gases to the sea surface, Atmos. Environ., 22, 1137-1146, doi:10.1016/0004-6981(88)90343-5, 1988.

Johnson, K. P., Blum, J. D., Keeler, G. J., and Douglas, T. A.: Investigation of the deposition and emission of mercury in arctic snow during an atmospheric mercury depletion event, J. Geophys. Res., 113, D17304, doi:10.1029/2008JD009893, 2008.

Kerbrat, M., Legrand, M. P., S., Gallée, H., and Kleffmann, J.: Nitrous acid at Concordia (inland site) and Dumont d'Urville (coastal site), east antarctica, J. Geophys. Res., 117, D08303, doi:10.1029/2011JD017149, 2012.

King, J. C. and Anderson, P. S.: Heat and water vapor fluxes and scalar roughness lengths over an Antarctic ice shelf, Bound.-Lay. Meteorol., 69, 101-121, 1994.

King, J. C., Argentini, S. A., and Anderson, P. S.: Contrasts between the summertime surface energy balance and boundary layer structure at Dome C and Halley stations, Antarctica, J. Geophys. Res., 111, D02105, doi:10.1029/2005JD006130, 2006.

King, M. D. and Simpson, W. R.: Extinction of UV radiation in Arctic snow at Alert, Canada ( $82^{\circ}$ N), J. Geophys. Res. 106, 12499 12507, 2001.

Kukui, A., Legrand, M., Preunkert, S., Frey, M. M., Loisil, R., Gil Roca, J., Jourdain, B., King, M. D., France, J. L., and Ancellet, G.: Measurements of $\mathrm{OH}$ and $\mathrm{RO}_{2}$ radicals at Dome C, East Antarctica, Atmos. Chem. Phys., 14, 1237312392, doi:10.5194/acp-14-12373-2014, 2014.

Lalonde, J. D., Amyot, M., Doyon, M.-R., and Auclair, J.-C.: Photoinduced $\mathrm{Hg}(\mathrm{II})$ reduction in snow from the remote and temperate experimental lakes area (Ontario, Canada), J. Geophys. Res., 108, 4200, doi:10.1029/2001JD001534, 2003.

Lambert, G., Ardouin, B., and Sanak, J.: Atmospheric transport of trace elements toward Antarctica, Tellus B, 42, 76-82, doi:10.1034/j.1600-0889.1990.00009.x, 1990.

Legrand, M., Preunkert, S., Jourdain, B., Gallée, H., Goutail, F., Weller, R., and Savarino, J.: Year-round record of surface ozone at coastal (Dumont d'Urville) and inland (Concordia) sites in east antarctica, J. Geophys. Res., 114, D20306, doi:10.1029/2008JD011667, 2009.

Legrand, M., Preunkert, S., Savarino, J., Frey, M. M., Kukui, A., Helmig, D., Jourdain, B., Jones, A., Weller, R., Brough, N., and Gallée, H.: Inter-annual variability of surface ozone at coastal (Dumont d'Urville, 2004-2014) and inland (Concordia, 2007-
2014) sites in East Antarctica, Atmos. Chem. Phys. Discuss., doi:10.5194/acp-2016-95, in review, 2016.

Lin, C.-J. and Pehkonen, S. O.: The chemistry of atmospheric mercury: a review, Atmos. Environ., 33, 2067-2079, 1999.

Lin, C.-J., Pan, L., Streets, D. G., Shetty, S. K., Jang, C., Feng, X., Chu, H.-W., and Ho, T. C.: Estimating mercury emission outflow from East Asia using CMAQ-Hg, Atmos. Chem. Phys., 10, 1853-1864, doi:10.5194/acp-10-1853-2010, 2010.

Lindberg, S. E., Brooks, S., Lin, C.-J., Scott, K. J., Landis, M. S., Stevens, R. K., Goodsite, M. E., and Richter, A.: Dynamic oxidation of gaseous mercury in the arctic troposphere at polar sunrise, Environ. Sci. Technol., 36, 1245-1256, 2002.

Lu, J. Y., Schroeder, W. H., Barrie, L. A., Steffen, A., Welch, H. E., Martin, K., Lockhart, L., Hunt, R. V., Boila, G., and Richter, A.: Magnification of atmospheric mercury deposition to polar regions in springtime: the link to tropospheric ozone depletion chemistry, Geophys. Res. Lett., 28, 3219-3222, 2001.

Mao, H. and Talbot, R.: Speciated mercury at marine, coastal, and inland sites in New England - Part 1: Temporal variability, Atmos. Chem. Phys., 12, 5099-5112, doi:10.5194/acp-12-50992012, 2012.

Mason, R. P., Choi, A. L., Fitzgerald, W. F., Hammerschmidt, C. R., Lamborg, C. H., Soerensen, A. L., and Sunderland, E. M.: Mercury biogeochemical cycling in the ocean and policy implications, Environ. Res., 119, 101-117, 2012.

Munthe, J., Sprovieri, F., Horvat, M., and Ebinghaus, R.: SOPs and QA/QC protocols regarding measurements of TGM, GEM, RGM, TPM and mercury in precipitation in cooperation with WP3, WP4 and WP5. GMOS deliverable 6.1, CNR-IIA, IVL., available at: http://www.gmos.eu (last access: 3 March 2014), 2011.

Neff, W., Helmig, D., Grachev, A. A., and Davis, D.: A study of boundary layer behavior associated with high NO concentrations at the South Pole using a minisodar, tethered balloon, and sonic anemometer, Atmos. Environ., 42, 2762-2779, 2008.

O'Concubhair, R., O'Sullivan, D. A., and Sodeau, J. R.: Dark oxidation of dissolved gaseous mercury in polar ice mimics, Environ. Sci. Technol., 46, 4829-4836, doi:10.1021/es300309n, 2012.

Pal, B. and Ariya, P. A.: Studies of ozone initiated reactions of gaseous mercury: kinetics, product studies, and atmospheric implications, Phys. Chem. Chem. Phys., 6, 572-579, 2004.

Parish, T. R. and Bromwich, D. H.: The surface windfield over the Antarctic ice sheets, Nature, 328, 51-54, 1987.

Parish, T. R. and Bromwich, D. H.: Reexamination of the nearsurface airflow over the Antarctic continent and implications on atmospheric circulations at high southern latitudes, Mon. Weather Rev., 135, 1961-1973, 2007.

Peleg, M., Tas, E., Obrist, D., Matveev, V., Moore, C., Gabay, M., and Luria, M.: Observational evidence for involvement of nitrate radicals in nighttime oxidation of mercury, Environ. Sci. Technol., 49, 14008-14018, 2015.

Perovich, D. K.: Light reflection and transmission by a temperate snow cover, J. Glaciol., 53, 201-210, 2007.

Pfaffhuber, K. A., Berg, T., Hirdman, D., and Stohl, A.: Atmospheric mercury observations from Antarctica: seasonal variation and source and sink region calculations, Atmos. Chem. Phys., 12, 3241-3251, doi:10.5194/acp-12-3241-2012, 2012.

Pietroni, I., Argentini, S., Petenko, I., and Sozzi, R.: Measurements and parametrizations of the atmospheric boundary-layer height 
at Dome C, Antarctica, Bound.-Lay. Meteorol., 143, 189-206, 2012.

Ricaud, P., Grigioni, P., Zbinden, R., Attié, J.-L., Genoni, L., Galeandro, A., Moggio, L., Montaguti, S., Petenko, I., and Legovini, P.: Review of tropospheric temperature, absolute humidity and integrated water vapor from the HAMSTRAD radiometer installed at Dome C, Antarctica, 2009-14, Antarct. Sci., 27, 598616, 2015.

Schroeder, W. H., Anlauf, K. G., Barrie, L. A., Lu, J. Y., Steffen, A., Schneeberger, D. R., and Berg, T.: Arctic spingtime depletion of mercury, Nature, 394, 331-332, 1998.

Seok, B., Helmig, D., Williams, M. W., Liptzin, D., and Chowanski, K. H., J.: An automated system for continuous measurements of trace gas fluxes through snow: an evaluation of the gas diffusion method at a subalpine forest site, Niwot Ridge, Colorado, Biogeochemistry, 95, 95-113, 2009.

Simpson, W. R., von Glasow, R., Riedel, K., Anderson, P., Ariya, P., Bottenheim, J., Burrows, J., Carpenter, L. J., Frieß, U., Goodsite, M. E., Heard, D., Hutterli, M., Jacobi, H.-W., Kaleschke, L., Neff, B., Plane, J., Platt, U., Richter, A., Roscoe, H., Sander, R., Shepson, P., Sodeau, J., Steffen, A., Wagner, T., and Wolff, E.: Halogens and their role in polar boundary-layer ozone depletion, Atmos. Chem. Phys., 7, 4375-4418, doi:10.5194/acp-74375-2007, 2007.

Slemr, F., Angot, H., Dommergue, A., Magand, O., Barret, M., Weigelt, A., Ebinghaus, R., Brunke, E.-G., Pfaffhuber, K. A., Edwards, G., Howard, D., Powell, J., Keywood, M., and Wang, F.: Comparison of mercury concentrations measured at several sites in the Southern Hemisphere, Atmos. Chem. Phys., 15, 31253133, doi:10.5194/acp-15-3125-2015, 2015.

Sprovieri, F., Pirrone, N., Hedgecock, I. M., Landis, M. S., and Stevens, R. K.: Intensive atmospheric mercury measurements at Terra Nova Bay in antarctica during November and December 2000, J. Geophys. Res., 107, 4722, doi:10.1029/2002JD002057, 2002.

Steffen, A., Schroeder, W., Bottenheim, J., Narayan, J., and Fuentes, J. D.: Atmospheric mercury concentrations: measurements and profiles near snow and ice surfaces in the Canadian Arctic during Alert 2000, Atmos. Environ., 36, 2653-2661, 2002.

Steffen, A., Douglas, T., Amyot, M., Ariya, P., Aspmo, K., Berg, T., Bottenheim, J., Brooks, S., Cobbett, F., Dastoor, A., Dommergue, A., Ebinghaus, R., Ferrari, C., Gardfeldt, K., Goodsite, M. E., Lean, D., Poulain, A. J., Scherz, C., Skov, H., Sommar, J., and Temme, C.: A synthesis of atmospheric mercury depletion event chemistry in the atmosphere and snow, Atmos. Chem. Phys., 8, 1445-1482, doi:10.5194/acp-8-1445-2008, 2008.

Steffen, A., Scherz, T., Oslon, M., Gay, D. A., and Blanchard, P.: A comparison of data quality control protocols for atmospheric mercury speciation measurements, J. Environ. Monitor., 14, 752765, doi:10.1039/c2em10735j, 2012.
Stohl, A. and Thomson, D. J.: A density correction for Lagrangian particle dispersion models, Bound.-Lay. Meteorol., 90, 155-167, 1999.

Stohl, A., Hittenberger, M., and Wotawa, G.: Validation of the Lagrangian particle dispersion model FLEXPART against large scale tracer experiments, Atmos. Environ., 32, 4245-4264, 1998.

Stohl, A., Forster, C., Frank, A., Seibert, P., and Wotawa, G.: Technical note: The Lagrangian particle dispersion model FLEXPART version 6.2, Atmos. Chem. Phys., 5, 2461-2474, doi:10.5194/acp-5-2461-2005, 2005.

Subir, M., Ariya, P. A., and Dastoor, A.: A review of uncertainties in atmospheric modeling of mercury chemistry I. Uncertainties in existing kinetic parameters - fundamental limitations and the importance of heteregeneous chemistry, Atmos. Environ., 45, 5664-5675, 2011.

Tekran: Tekran 2537 mercury monitor detection limit. Summary of known estimates, Tekran Instruments Corp., Toronto, ON, Canada, 2011.

Temme, C., Einax, J. W., Ebinghaus, R., and Schroeder, W. H.: Measurements of atmospheric mercury species at a coastal site in the antarctic and over the atlantic ocean during polar summer, Environ. Sci. Technol., 37, 22-31, 2003.

UNEP: Text of the Minamata Convention on Mercury for adoption by the Conference of Plenipotentiaries, unep.org. July 31, available at: http://www.unep.org/ hazardoussubstances/Portals/9/Mercury/Documents/dipcon/ CONF_3_MinamataConventiononMercury_final2608_e.pdf (last access: 27 March 2016), 2013.

Wang, F., Saiz-Lopez, A., Mahajan, A. S., Gómez Martín, J. C., Armstrong, D., Lemes, M., Hay, T., and Prados-Roman, C.: Enhanced production of oxidised mercury over the tropical Pacific Ocean: a key missing oxidation pathway, Atmos. Chem. Phys., 14, 1323-1335, doi:10.5194/acp-14-1323-2014, 2014.

Weiss-Penzias, P., Jaffe, D. A., Swartzendruber, P., Hafner, W., Chand, D., and Prestbo, E.: Quantifying Asian and biomass burning sources of mercury using the $\mathrm{Hg} / \mathrm{CO}$ ratio in pollution plumes observed at the Mount Bachelor observatory, Atmos. Environ., 41, 4366-4379, 2007.

Xiao, W., Liu, S., Li, H., Xiao, Q., Wang, W., Hu, Z., Hu, C., Gao, Y., Shen, J., Zhao, X., Zhang, M., and Lee, X.: A flux-gradient system for simultaneous measurement of the $\mathrm{CH}_{4}, \mathrm{CO}_{2}$, and $\mathrm{H}_{2} \mathrm{O}$ fluxes at a lake-air interface, Environ. Sci. Technol., 48, 14490-14498, 2014.

Zhang, L., Wright, L. P., and Blanchard, P.: A review of current knowledge concerning dry deposition of atmospheric mercury, Atmos. Environ., 43, 5853-5864, 2009. 